\title{
A Geospatial Expose of Flood-Risk and Vulnerable Areas in Nigeria
}

\author{
Chukwudi Gbadebo Njoku, University of Calabar, Nigeria \\ (iD) https://orcid.org/0000-0003-0657-0058 \\ Joel Efiong, University of Calabar, Nigeria \\ Nse-Abasi Ndiyo Ayara, University of Calabar, Nigeria
}

\begin{abstract}
Flooding is recurrent in Nigeria, occurring yearly at different scales. This geared the need for a study to reveal local government areas (LGAs) that are at risk and vulnerable to flooding. The multi-criteria approach was adopted, using geospatial techniques and data. Factors considered were elevation, slope, rainfall intensity, and distance to river. The factors were classified, reclassified, rated, and weighed in a systematic process. Nineteen states and 114 LGAs face high risks, especially communities in the Niger Delta, around the lagoons of Lagos, along River Niger, Benue, and the Cross-River. Also, 125 LGAs in 18 states face medium flood-risk vulnerability. Consideration the population density of communities, Lagos State is the most vulnerable because of LGAs with high population densities within high flood-risk zones. Other states with communities exposed to high flood-risk vulnerability include Rivers, Kogi, Cross River, Akwa Ibom, Anambra, and Delta. The study provides information key to proactive policy formulation, mitigation, and adaptation to flood risk in Nigeria.
\end{abstract}

\section{KEYWORDS}

Flooding, Flood-Risk Zones, Geographic Information Systems, Multi-Criteria Analysis, Vulnerability

\section{BACKGROUND TO THE STUDY}

The past two decades have seen a significant upsurge in the frequency of flooding on a global scale (Najibi \& Devineni, 2017). The Intergovernmental Panel on Climate Change (IPCC) confirmed that flood vulnerability would most likely increase in line with increasing rainfall events (Conix \& Bachus, 2007). The occurrence of flooding around the world is fast becoming a normality (Thomalla, Downing, Spanger-Siegfried, Han \& Rockström, 2006) with about 70 million people exposed to flood risk and at least 800 million people susceptible (Peduzzi, Dao, Herold \& Mouton, 2009). Its impacts are as well immeasurable. For example, in the United States, floods destroy property worth US\$6 billion and kill 140 people annually (National Geographic, 2018).

In Nigeria, flooding is a recurrent phenomenon which could be coastal, fluvial or pluvial (Aderogba, 2012). Coastal and fluvial flooding in Nigeria affects coastal and riverine environments and are due to seasonal water upsurge from large rivers such as the Niger, Benue, Cross River, Kaduna, 
and others. On the other hand, pluvial floods are yearly occurrences during the rainy season (from July to October) and are more eminent in the cities (Nkwunonwo, Malcolm \& Brian, 2015). Recent flood occurrences in Nigeria have been particularly, among other factors, geared by the release of water from the Lagdo Dam in Cameroon (Udo, Ojinnaka, Baywood \& Gift, 2015), the high intensity of rainfall in some regions (Eagle Online, 2018) and the haphazard development of land on flood prone areas (Atufu \& Holt, 2018).

Flooding is the most occurring natural hazard in Nigeria and the situation is dire (Aderogba, 2012). An early account of flooding in Nigeria is the Ogunpa River flooding of Ibadan in 1963, 1978, 1980 and 2011, which led to an estimated property loss of at least 30 billion naira and 100 fatalities. In Lagos, there were at least 8 flood events that killed at least 30 people between 2011 and 2012 (Komolafe, Adegboyega \& Akinluyi, 2015). Whereas flooding has been a recurrent occurrence in Nigeria, the year 2012 event was a striking one, superseding previous flood events in the last 40 years. The National Emergency Management Agency (NEMA) reported that it affected 7 million people in 30 states, displaced 2.3 million people, killed 363 and cost Nigeria's economy an estimated loss of US\$ 9.6 billion (Amangabara \& Obenade, 2015).

Earlier studies have examined flooding and flood-risk in Nigeria as a whole (Nkwunonwo, Malcolm \& Brian, 2015; Komolafe, Adegboyega \& Akinluyi, 2015), while others assessed the problem at a regional or state level (Amangabara \& Obenade, 2015; Udo, Ojinnaka, Baywood \& Gift, 2015; Udo \& Eyoh, 2017, Efiong \& Hogan, 2017). The question of "which Local Government Areas (LGAs) in Nigeria are most at risk to flooding and which are more vulnerable?" has however received no empirical attention. Providing answers to these questions are key to flood mitigation and adaptation in Nigeria and elsewhere. The geospatial technologies of remote sensing and geographic information systems (GIS) have proven to be of immense value in this regard.

GIS and remote sensing techniques have become indispensable tools for mapping flood-risk vulnerability (Karmakar, Simonovic, Peck \& Black, 2010, Wicht \& Osinska-Skotak, 2016; Das, Chattopadhya \& Basu, 2017; Gandini, Prieto, Garmendia, San-Jose \& Egusquiza, 2018), providing evidence for early warning and emergency response systems.

GIS tools in a multi-criteria approach (MCA) combines causative natural factors to derive flood vulnerability classes that support flood risk mitigation (Daneshbod, 2014; Elsheikh, 2015; Blistanova, Zelenakova, Blistan \& Ferencz, 2016). In this vein, Meena \& Gupta (2017) integrated multiple parameters such as rainfall, slope, drainage density, land use, building density and so on to make deductions. Similarly, Danumah, et al. (2016) integrated parameters such as slope, drainage density, type of soil, isohyet, population density, land use and sewer system density. Njoku, Efiong, Uzoezie, Okeniyi \& Alagbe (2018) also combined independent parameters (distance from river, rainfall intensity, elevation, land use, slope and soil- "DRELSS") to evaluate flood-risk vulnerability.

These parameters in the MCA are usually assigned different weights, based on the influence of the variable on flood occurrence. This weighting process, termed the weighted overlay analysis has gained popularity in the spatial flood risk-vulnerability mapping process (Liu, 2013; Mokarram \& Hojati, 2017). The selection of appropriate weights and ranks in the MCA process is fundamental in the vulnerability assessment (Hoque, Pradhan \& Ahmed, 2019). Some authors have depended on the situation in the field, backed by literature (Udani \& Mathur, 2016; Ajjur \& Mogheir, 2020), while some others have adopted the Analytical Hierarchy Process (AHP) to compute the priority weights of factors (Umar, Abdullahi \& Usman, 2019; Hoque, Pradhan \& Ahmed, 2019; Fadhil, Ristya, Oktaviani \& Kusratmoko, 2019). Despite these differences, there is a consensus that the MCA is most suitable for decisions on flood mitigation and land use planning (Ogato, Bantider, Abebe \& Geneletti, 2020).

Notably, tackling flooding and reducing its associated risks in Nigeria has been an uphill task because of some cardinal gaps highlighted by Nkwunonwo, Malcolm \& Brian (2015). Even when flood vulnerability is modeled, a major gap still exists between what the 
models can provide and what local practitioners need (Liu, et al., 2018). Location-based knowledge which is lacking in Nigeria, is key in informing flood management (Brierley et al., 2013). The current trend of flood occurrences and impacts in Nigeria calls for more studies and accurate spatial information on the potential flood hazards (Umar, Abdullahi \& Usman, 2019). The dearth of studies that holistically adopt GIS in planning for flood disaster in Nigeria means there is a crucial need to explore more effectively, the use of recent geospatial methods and data for flood hazard mapping, exposure and vulnerability (Komolafe, Adegboyega \& Akinluyi, 2015; Efiong \& Ushie, 2019). This highlights the need for flood-risk and vulnerability maps as well as information that would be effectively communicated to decision makers, emergency response units and the public (Yahaya \& Abdalla, 2010; Fadhil, Ristya, Oktaviani \& Kusratmoko, 2019).

This study attempts to fill these gaps and serves as a baseline for decision making and further studies on flood-risk vulnerability in Nigeria. It focused on revealing through maps, LGAs at risk of flooding in Nigeria and further highlights areas of high and medium vulnerability due to the prevalence of high population densities within high flood-risk zones. It demonstrates the power of GIS and remote sensing in overcoming the dearth of field data needed to model flood-risk vulnerability. The study starts by introducing the flooding problem in Nigeria, presents the data sets used and multi-criteria method employed. It further elaborates on the processes that led to the deduction of flood-risk zones and LGAs that are vulnerable to flood-risk in Nigeria.

\section{The Concept of Risk and Vulnerability}

Vulnerability implies the potential for loss, considering the nature of a hazard, who and what are exposed to it (Karmakar, Simonovic, Peck \& Black, 2010). Flood vulnerability is thus the degree to which a person, people or place are at risk of flooding and its adverse effects (Conix \& Bachus, 2007). Consequently, risk infers the "the probability that a hazard would occur and trigger a disaster or series of events with an undesirable outcome" (Brooks, 2003). It is the probability of a loss that depends on three elements; hazard, vulnerability and exposure (Crichton, 1999). There is a strong relationship between hazard and vulnerability, both of which cannot exist independently (Cardona, 2004). Hazard is "an event with the potential to cause harm" (Brooks, 2003) while vulnerability is examined in this study as the specific sense of an aggregate measure of exposure to the risk of flooding. It is adopted as the risk indicator in this study because of its importance to the risk discourse (Musungu, Motala \& Smit, 2012).

Flood-risk vulnerability is a function of natural and anthropogenic factors (Danumah, et al., 2016). While the natural factors, like excessive rainfall (Kim \& Kim, 2014), topography and soil type (Rimba, Setawati, Samba \& Miura, 2017) may be uncontrollable, the man-made activities such as an intentional sprawl to the riverbanks, deforestation, etc. (Billi, Alemu \& Ciampalini, 2015; Forkuo, 2013), aggravate vulnerability levels. In view of this, Wilde's risk homeostasis theory states that "individuals and communities maintain a specific level of risk irrespective of external influences". For instance, the perceptions and defenses that make people reside very close to rivers and in flood plains despite the unpredictable behaviour of the river which increases their vulnerability to risk (Wilde, 1982).

People are becoming more vulnerable to flooding due to a combination of natural and anthropogenic activities resulting from socio-economic necessities (Blistanova, Zelenakova, Blistan \& Ferencz, 2016). What may not be possible is man's ability to stop the occurrence of flooding. What is possible however, is man's ability to become less vulnerable and minimize the impacts. This follows from the idea of environmental possibilism which provides that humans are able to use tools and technology to either alter or address environmental concerns. 


\section{MATERIALS AND METHODS}

\section{Study Area}

Nigeria is a West African country, located within latitudes $4^{\circ} 16^{\prime} 13.50^{\prime \prime}$ and $13^{\circ} 53^{\prime} 31.24^{\prime \prime}$, North of the Equator and longitudes $2^{\circ} 40^{\prime} 6.35^{\prime \prime}$ and $14^{\circ} 40^{\prime} 35.09^{\prime \prime}$, East of the Greenwich Meridian. It is bordered by Niger Republic in the North, Benin Republic in the West, the Atlantic Ocean's Gulf of Guinea in the South as well as Chad Republic and the Republic of Cameroon to the East (Figure 1).

Figure 1. Map of Nigeria

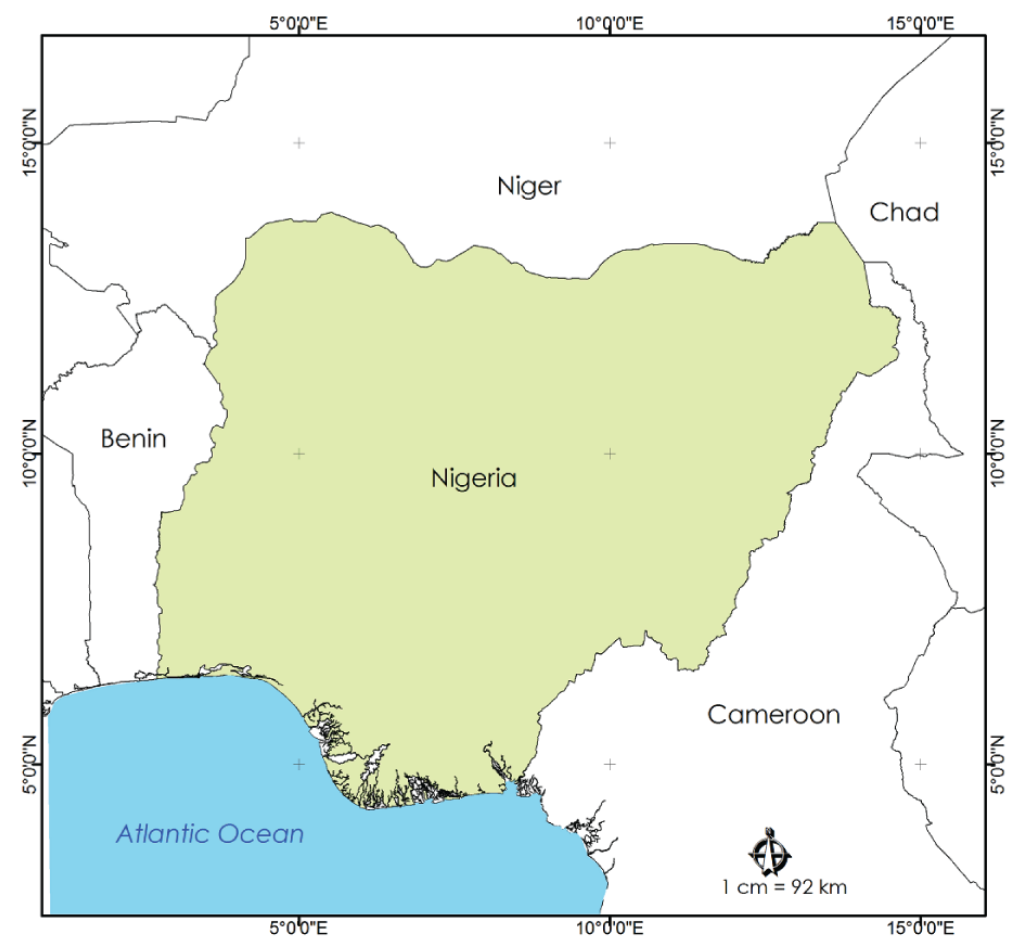

Nigeria has 36 States, a Federal capital Territory- FCT (Abuja) and 774 LGAs. It has a total land area of 924,000 $\mathrm{km}^{2}$ and a population estimate of 173 million in 2015 (Africa Development Bank, 2017).

The Country has diverse topography with a variety of relief features, including uplands of 600 to $1,500 \mathrm{~m}$ above mean sea level in the North Central and the East highlands, as well as lowlands of less than 20 meters above mean sea level in the coastal areas (Ademiluyi, Okude \& Akanni, 2008).

Also, Nigeria is endowed with abundant natural water resources evident in her substantial yearly rainfall, large surface water bodies and abundant reservoirs of underground water (Ojiakor, 2009). The principal rivers in the country are the Niger and its main tributary, the Benue. Both rivers are navigable over most of their courses and together drain the greater part of Nigeria. The country has a tropical climate that varies from south to north and is influenced by elevation. Southern Nigeria faces warm, moist, south-westerly winds from the sea during much of the year and is hot, humid, and oppressive. Temperature averages about $27^{\circ} \mathrm{C}\left(80^{\circ} \mathrm{F}\right)$ with small daily and seasonal variations (Fashae, Olushola \& Adedeji, 2017). Annual precipitation is below 500 millimeters in the north, ranges from 1000 to $1500 \mathrm{~mm}$ in the central region and exceeds $2000 \mathrm{~mm}$ in the south. All these geographical 
characteristics make flood occurrence possible in the country, with temporal and spatial variations in occurrence and vulnerability.

\section{Analytical Framework}

This study employed the MCA approach to develop a flood-risk map to reveal LGAs that are vulnerable to flood-risk in Nigeria. The MCA enables the combination of different geospatial datasets (elevation, slope, rainfall, and distance to water bodies) to derive results. The MCA approach is more suitable for this study because it combines geographical data and a set of preferences to provide the best results for decision making (Malczewski \& Rinner 2015; Fadhil, Ristya, Oktaviani \& Kusratmoko, 2019). The flow chart (Figure 2) summarizes the step-by-step approach adopted, highlighting data sets, processes and results derived.

\section{Figure 2. Flow chart}

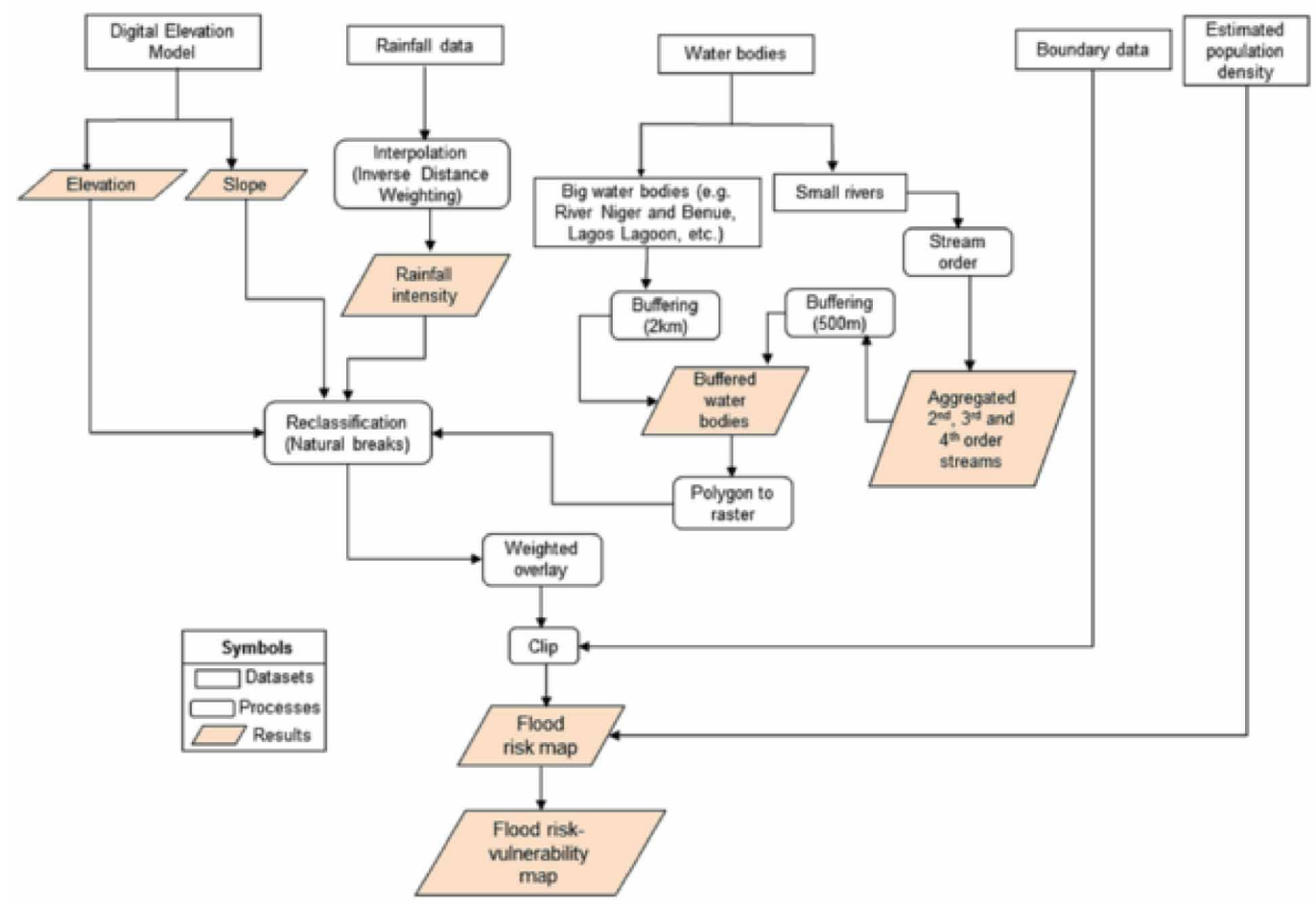

\section{Data Types and Sources}

The data used in this study include the Digital Elevation Model (DEM), rainfall intensity, population density data and shapefiles of water bodies, state and LGA administrative boundaries. These data were sourced from secondary sources (Table 1) and served as basis to generate other points, lines, polygons and pixel-based data used in the study. Online news platforms and technical reports from renowned organizations also provided statistics related to flood events in Nigeria.

\section{Parameter Inputs}

To map flood-risk zones in Nigeria, the selection of effective parameters is vital. Although it is difficult to choose factors unanimously, some important variables have definitive roles (Samanta, 
Table 1. Data types and sources

\begin{tabular}{|l|l|l|c|}
\hline \multicolumn{1}{|c|}{ S/n } & \multicolumn{1}{|c|}{ Data } & \multicolumn{1}{c|}{ Data Source } & Year \\
\hline 1 & DEM & United States Geological Survey (USGS) Google Earth & \\
\hline 2 & Rainfall intensity & $\begin{array}{l}\text { Nigeria Meteorological Agency (NIMET) Seasonal Rainfall } \\
\text { Prediction (2017) }\end{array}$ & 2017 \\
\hline 3 & $\begin{array}{l}\text { Estimated population } \\
\text { density }\end{array}$ & World Bank (2018) & 2015 \\
\hline 4 & $\begin{array}{l}\text { Boundary and water body } \\
\text { shapefiles }\end{array}$ & Humanitarian Data Exchange (2018) & 2018 \\
\hline
\end{tabular}

Koloa, Pal \& Palsamanta, 2016). Different geospatial data sets, such as topography (elevation and slope), rainfall intensity and distance to water bodies were considered as independent parameters in this study. The inability to incorporate other parameters such as soil and land-use characteristics which would have made for a more robust flood-risk modelling and vulnerability assessment presents a gap in this study. This gap is geared by the difficulty in accessing data such as a high-resolution open access satellite imagery or a raster-based soil map for the whole Nigeria.

Topography plays a vital role in the spread of flood water and is key to flood extent estimation (Horritt \& Bates, 2002). Invariably, places that have low elevations are more liable to flooding (Njoku, Efiong, Uzoezie, Okeniyi \& Alagbe, 2018). Topographic parameters of elevation (Figure 3) and slope

Figure 3. Elevation classes in Nigeria

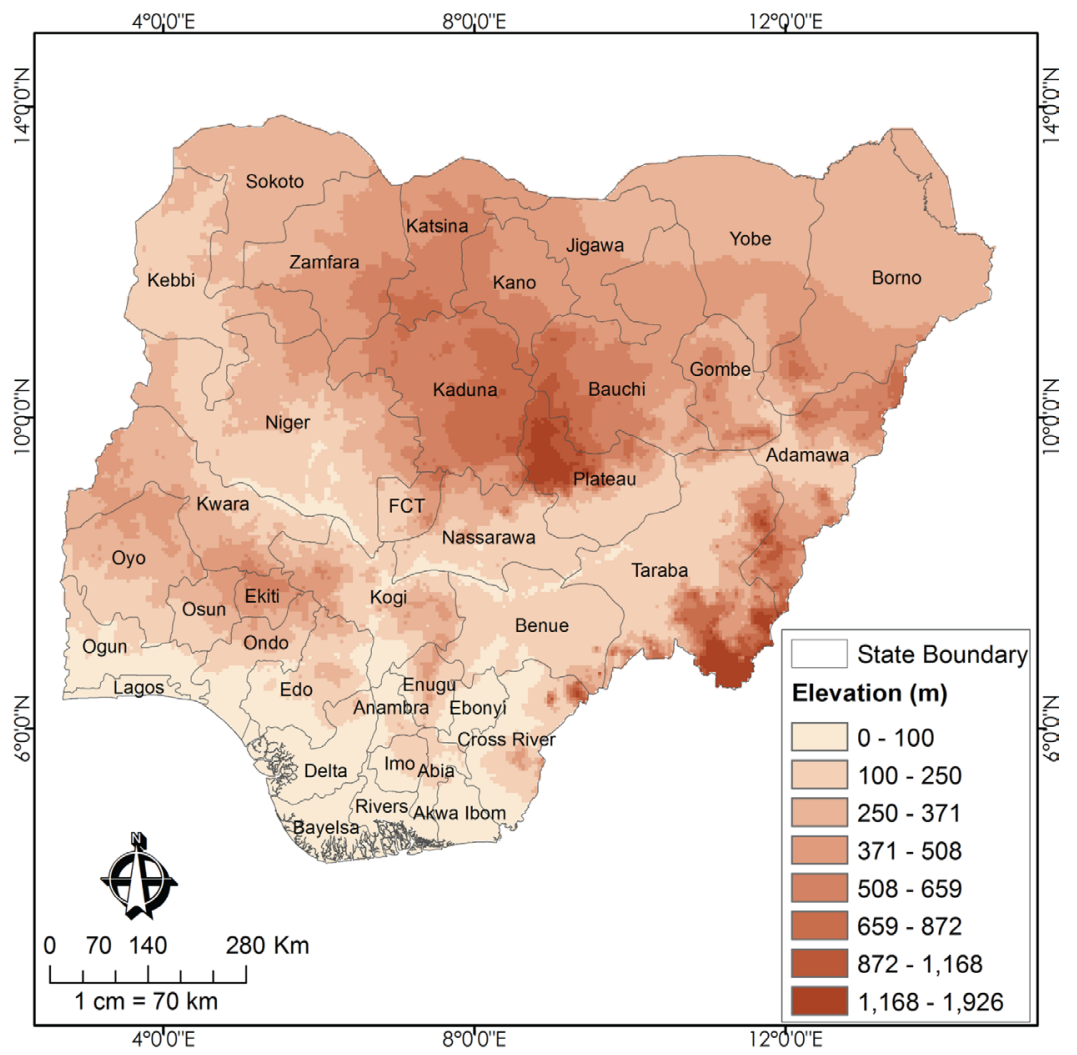


(Figure 4) were derived from the DEM which is a gridded digital representation of terrain which has each pixel value corresponding to a height above a datum (Hawker, Bates, Neal \& Rougier, 2018). The DEM was generated using location data (X, Y) obtained from USGS Google Earth platform and elevation values $(\mathrm{Z})$ were extracted using the TCX Converter application. Based on the $\mathrm{X}, \mathrm{Y}, \mathrm{Z}$,

\section{Figure 4. Slope classes in Nigeria}

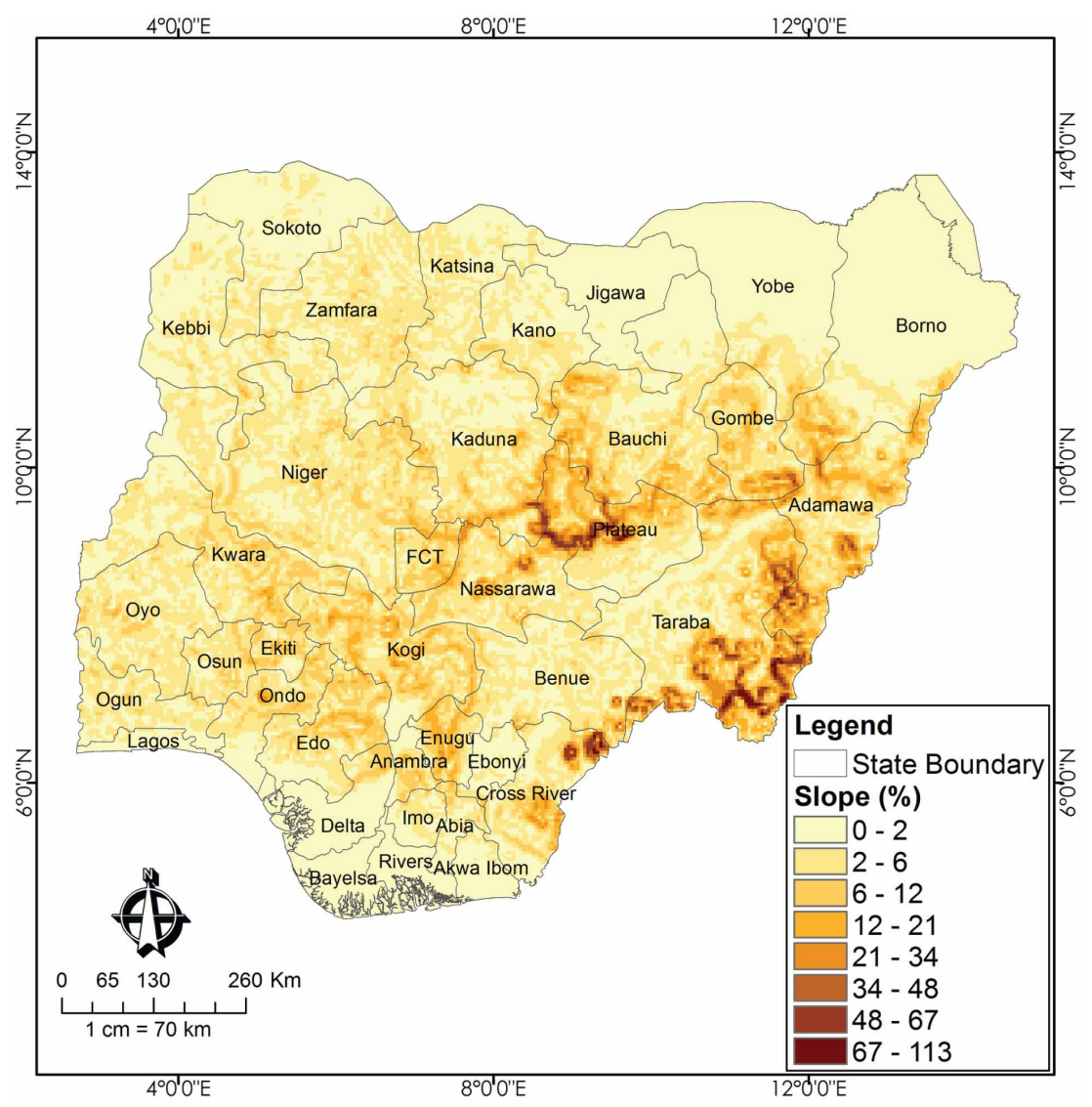

the DEM was generated using the Inverse Distance Weighting (IDW) interpolation tool. The rainfall intensity zones map (Figure 5) was also generated from the rainfall data using the $I D W$.

Flooding in Nigeria is largely fluvial (Aderogba, 2012) and communities in the vicinity of rivers are more vulnerable to flood risks (Fernandez \& Lutz, 2010; Kazakis, Kougias \& Patsialis, 2015). Thus, the water body shapefiles which included the large rivers and lakes represented by polygons and the smaller rivers, represented by lines were prepared for analyses. The smaller rivers are numerous; thus, they were ordered from stream one to four (Figure 6) according to the Strahler's (1957) classification. The streams were further reduced and aggregated to the important second, third and fourth order streams (Figure 7) using the stream order spatial analyst tool.

The proximity analysis was used to create buffers from the water body data sets using the single ring buffering tool. A buffer of $2 \mathrm{~km}$ was done for the large water bodies such as River Niger, Benue River, Cross River, Lagos Lagoons, and so on. For the smaller rivers, after reducing them to the important streams, a $500 \mathrm{~m}$ buffer was performed. Both buffer outputs were combined into one map (Figure 8). Similar to previous studies (Suleiman, Matazu, Davids \& Mozie, 2014; Samanta, Koloa, 


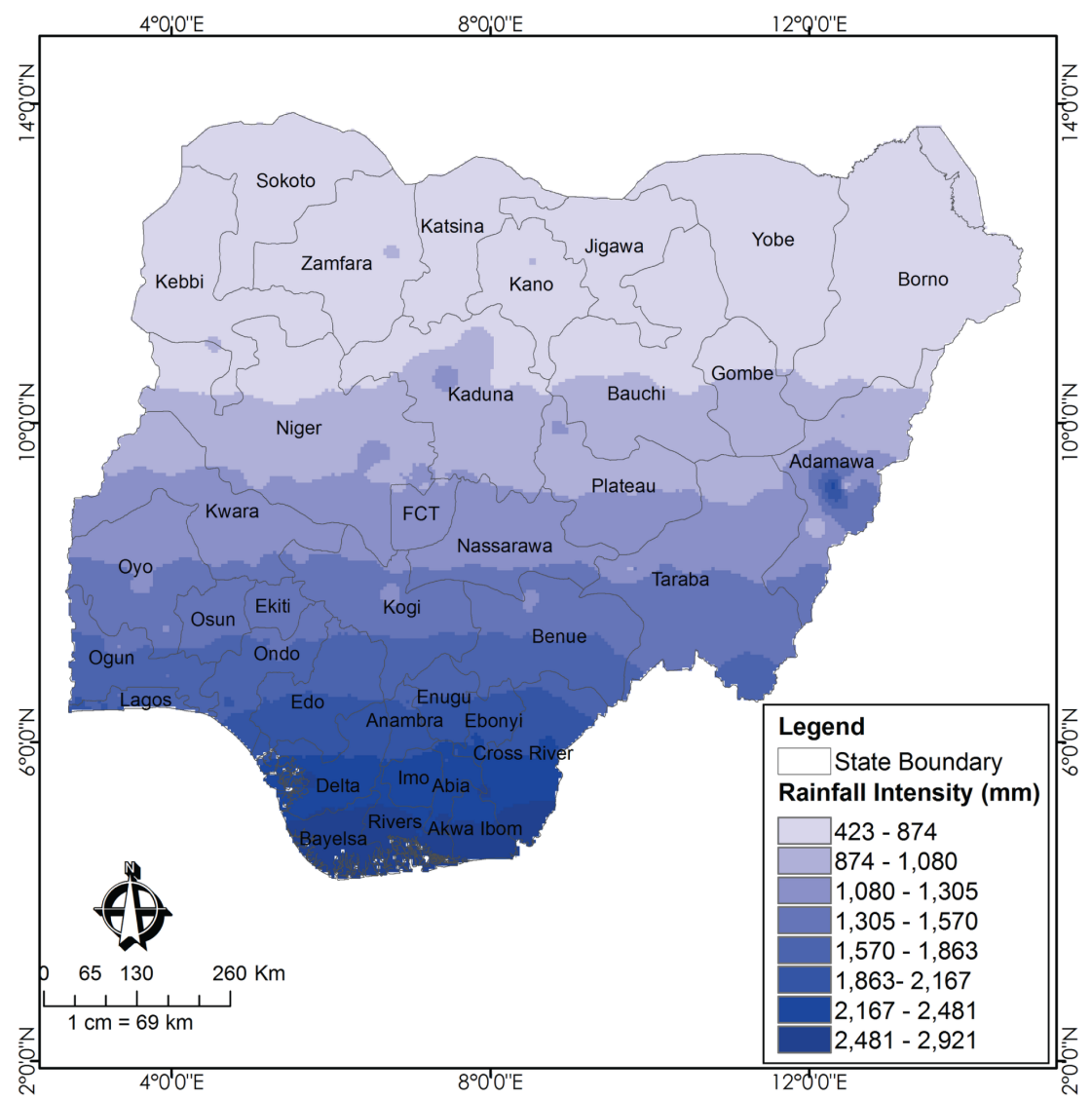

Pal \& Palsamanta, 2016; Kazakis, Kougias \& Patsialis, 2015), the buffer distance considered from the edge of the river is user-defined based on the history of the extent that is inundated when the river overflows. Since the other parameters (elevation, slope, rainfall intensity) were already in raster format, only the water body layers were converted to raster from their initial vector state. This was to enable the execution of the weighted overlay analysis.

The World Bank raster data also provided estimates of the density of people residing in each $100 \times 100 \mathrm{~m}$ grid cell in Nigeria. This estimated population density data aided to determine the LGAs that are most vulnerable to flooding considering potential impacts of flooding on more populated communities compared to less populated areas.

\section{Reclassification and Rating Process}

The data were reclassified using the natural breaks grading method. The DEM was reclassified into 8 classes (Figure 9). Also, the slope map was reclassified into 7 classes (Figure 10); rainfall intensity into 3 classes (Figure 11), and the water bodies into one class.

Furthermore, rates and rating indexes were assigned for all the classes of each parameter based on the reclassification (Table 2). After preparation of all parameters and their individual classes, user-defined rates on a scale of 1 to 8 were assigned for DEM; 1 to 7 for slope; 1 to 3 for rainfall intensity and, 1 for proximity to rivers and water bodies. 


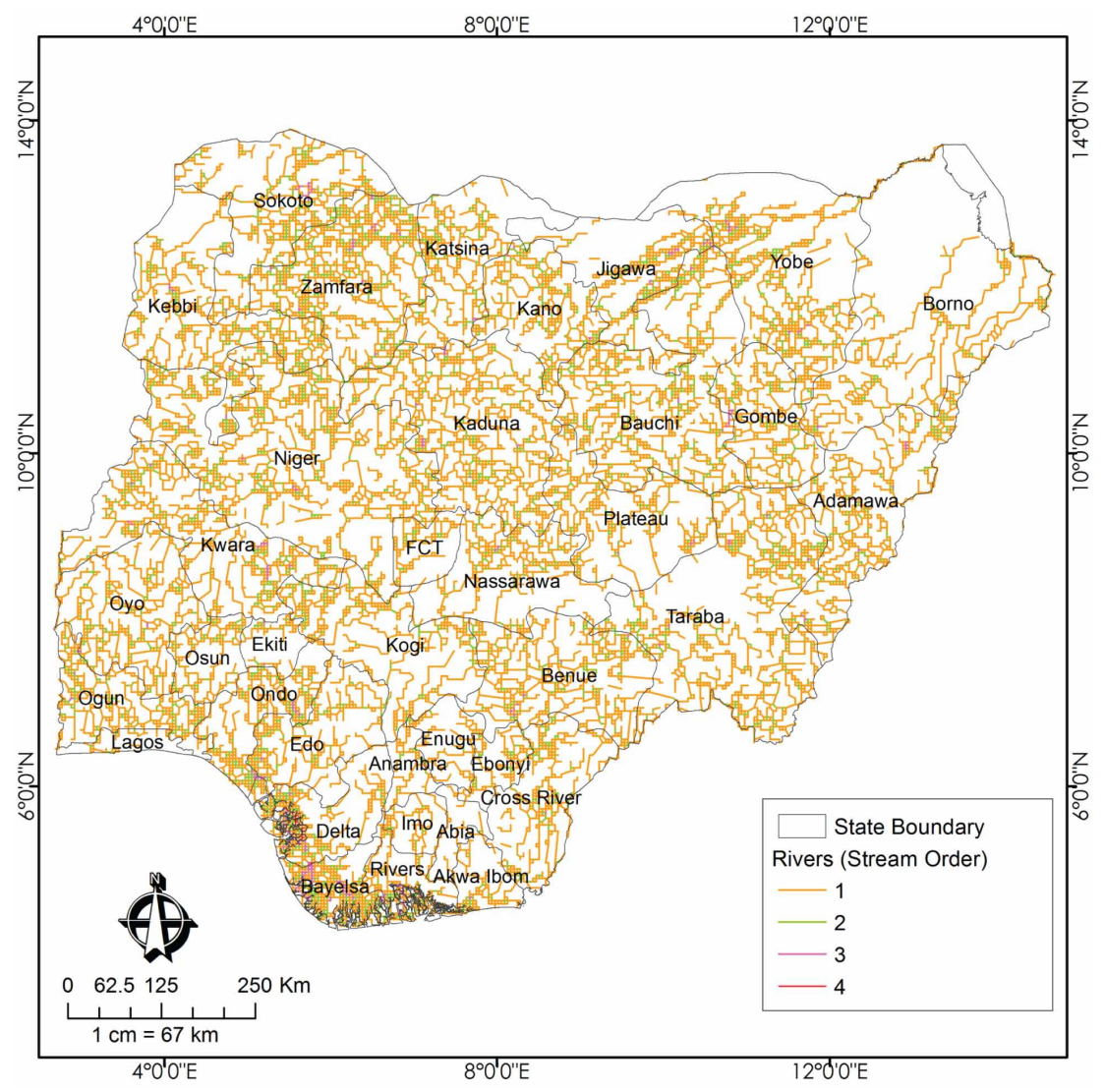

Locations with elevation less than $100 \mathrm{~m}$ were rated as high-risk areas and elevations more than $100 \mathrm{~m}$ assigned low risk status. Also, areas with slopes less than $10 \%$ have higher susceptibility to flooding than those more than 10\% (Samanta, Koloa, Pal \& Palsamanta, 2016; Orok, 2011). As well, higher rainfall intensity implies higher possibilities of flooding and vice versa (Rimba, Setawati, Samba \& Miura, 2017), thus the rating of rainfall intensity area with less than $1000 \mathrm{~mm}$ of rainfall as low and areas with more than $1000 \mathrm{~mm}$ of rainfall as high-risk zones (Table 2). For DEM and slope, the lowest rating index (1) refers to extreme risk while the higher rates represent low risk zones. For rainfall, 1 alternatively represents low risk, being the rating index for areas with lower rainfall intensity. The rating index of 1 was also assigned as high risk for the areas which are located less than 500m from the smaller rivers and $2000 \mathrm{~m}$ from the bigger water bodies. These rates and rating indexes are user-defined, based on literature and depending on their influence on flood-risk (Samanto, Koloa, Pal \& Palsamanta, 2016, Gigović, Pamučar, Bajić \& Drobnjak, 2017, Ajjur \& Mogheir, 2020).

\section{Weighting Process}

The weighted overlay process was used to integrate the rates and weights (Table 2) and to generate a flood-risk map of Nigeria (Figure 12). Similar to Umar, Abdullahi \& Usman (2019), the map was classified into a 3-point rank scale thus: high, medium and low risk zones. The low risk zones refer to areas where the chances of flood occurrences are about zero and high-risk zones refer to the areas where flood can occur at any time due to seasonal as well as sporadic heavy rainfall, overflow of 
Figure 7. Aggregated second, third and fourth order streams

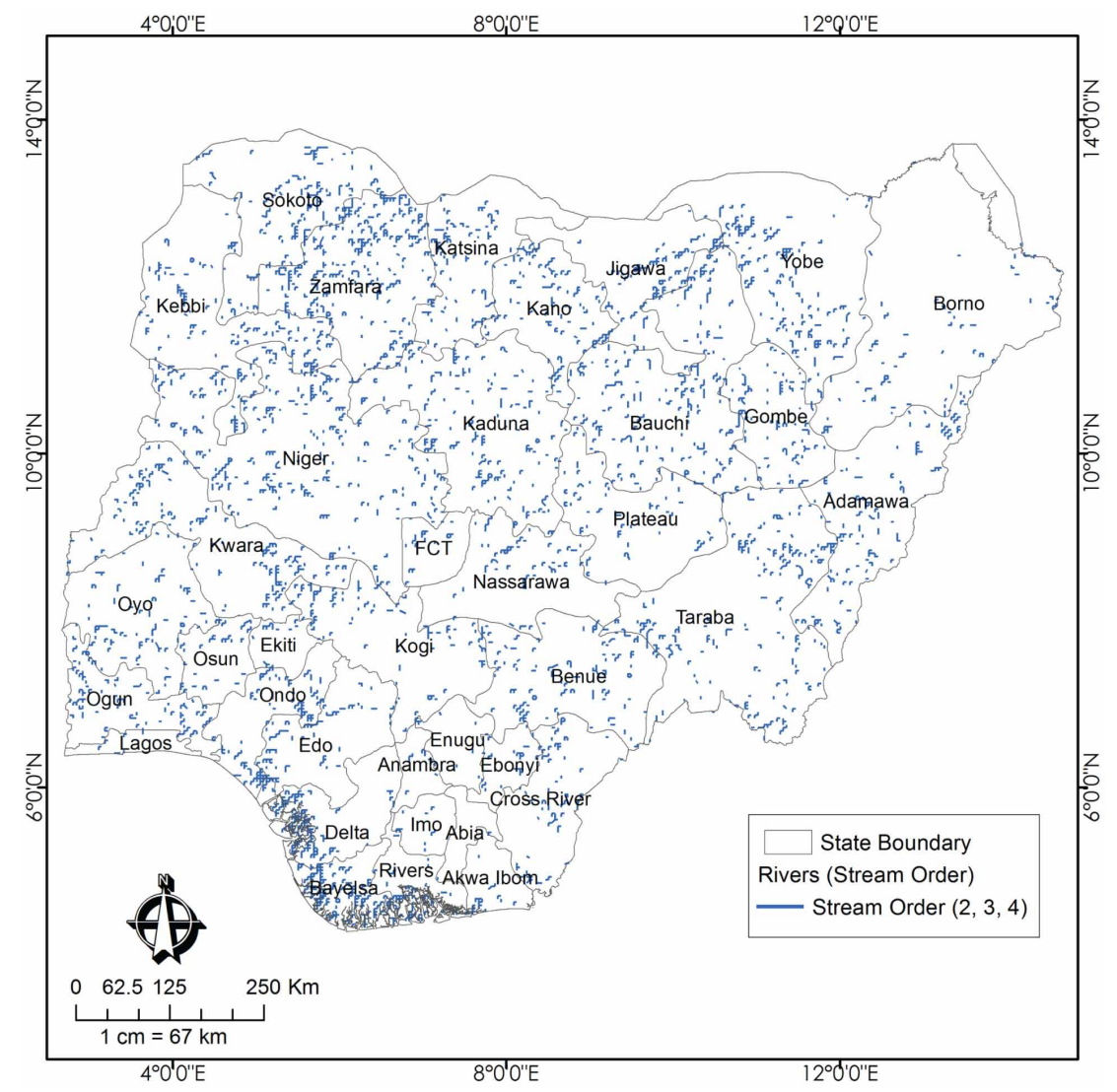

dams, increase in ocean water level and other natural or anthropogenic vagaries. The medium risk are the areas also prone to inundation, but not as severe as the high-risk zone.

Weights were allocated for the parameters to make a final decision on flood risk zones and vulnerable LGAs. The weighted overlay analysis was executed using the weighted overlay spatial analyst tool. This tool overlays several raster datasets using a common measurement scale and weighs each according to its importance (ESRI, 2014).

The weight assigned to each parameter determines its role in the final output. This is usually based on the relevance of each factor, backed by the observed behavior of previous flood events in the area and literature. Authors who have adopted the weighted overlay analyses have uniquely selected their weighing preferences. For example, Rimba, Setawati, Samba \& Miura (2017) allocated the highest weight to slope. Siddayao, Valdez \& Fernandez (2014) and Samanta, Koloa, Pal \& Palsamanta (2016) assigned the highest influence to the distance from river, Ouma \& Tateshi (2014) assigned the highest weight to soil type, while for Kazakis, Kougias \& Patsialis (2015), flow accumulation was assigned the highest influence.

In this study, a total weight of 100 was assigned to all the 4 reclassified parameters (elevation, slope, rainfall intensity and buffer of proximity to water bodies). A weight of 20 was assigned to the distance from large water bodies because the most affected areas during floods are those near rivers, as a consequence of river bank overflow. The slope of the topography also plays an important role in determining surface runoff velocity and rate of vertical percolation; thus, it was assigned a weight of 20. Further, elevation has an important impact on the spread of flooding 


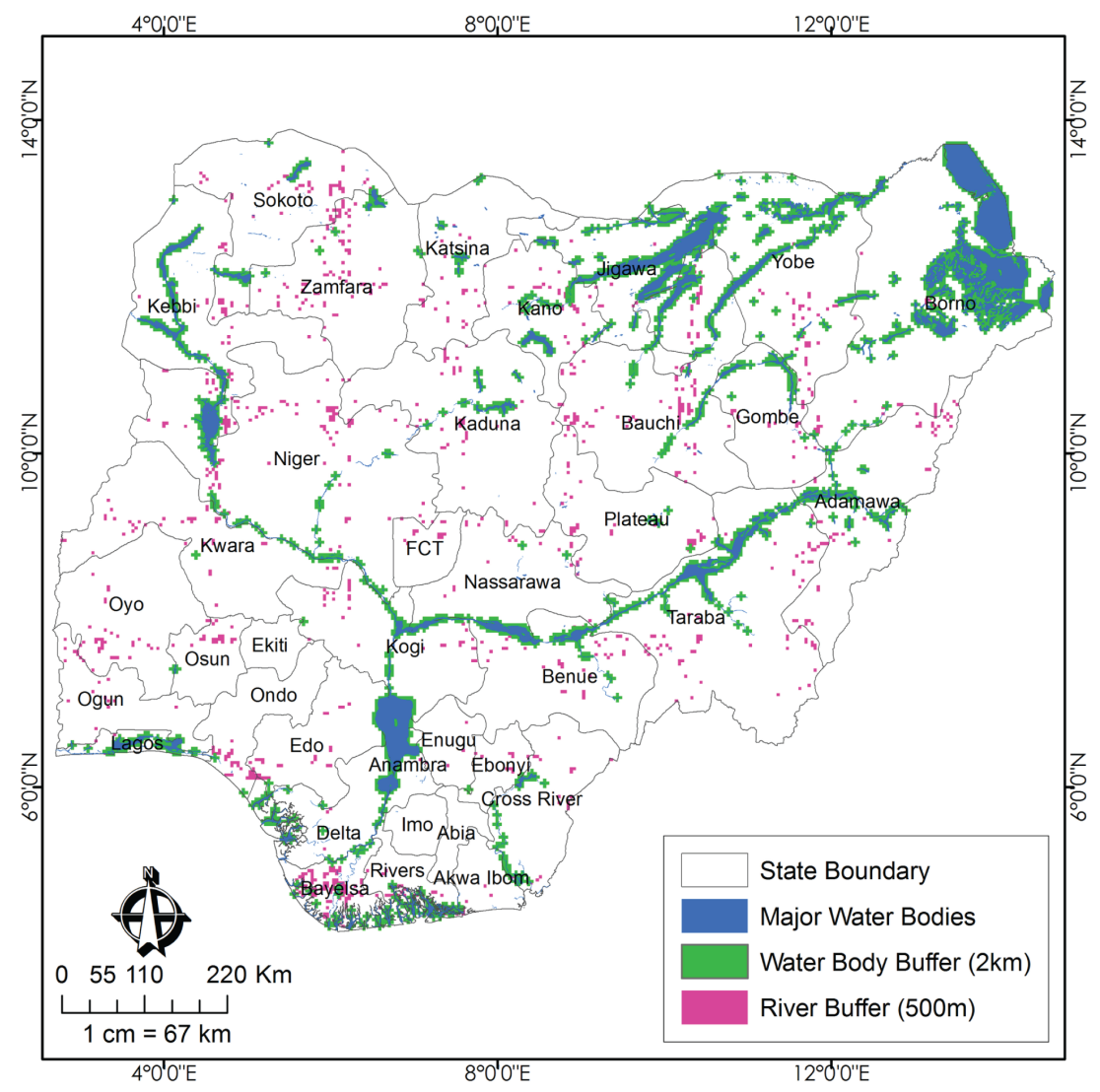

and has a key role in the control of the direction of overflow movement and also in the depth of the flood, thus, the highest weight of 30 . Rainfall intensity also plays a significant role as most flood events are triggered by rainfall, thus a weight of 20 was allotted. The other smaller rivers were also assigned a weight of 10 (Table 2).

The raster output of the weighted overlay analysis was a flood-risk zones map which was polygonized to enable measurements. Furthermore, to aid deductions of flood-risk vulnerability in Nigeria, the polygonized flood-risk map was overlaid on the population density map which was classified into $3(<1=$ low density, 1-2 = medium and 2-3 = high density). The unit of measurement for the population density map is given as "persons per $200 \mathrm{~m}^{2}$ grid".

\section{RESULTS AND DISCUSSIONS}

\section{Flood-Risk Vulnerable LGAs in Nigeria}

A total of 33 out of 36 States and the FCT in Nigeria are faced with high and medium flood-risks. Table 3 shows the LGAs that are at high vulnerability to flooding while Table 4 shows LGAs that are at medium vulnerability to flooding. A total of 12 States in the South of Nigeria have LGAs in high flood-risk zones while in the North, there are seven States with LGAs within high flood-risk zones. In all, 19 States and 114 LGAs (14\% of all the LGAs in Nigeria) are exposed to high flood-risks with hotspots majorly at the Niger Delta, the Lagoons of Lagos, along the River Niger, River Benue 


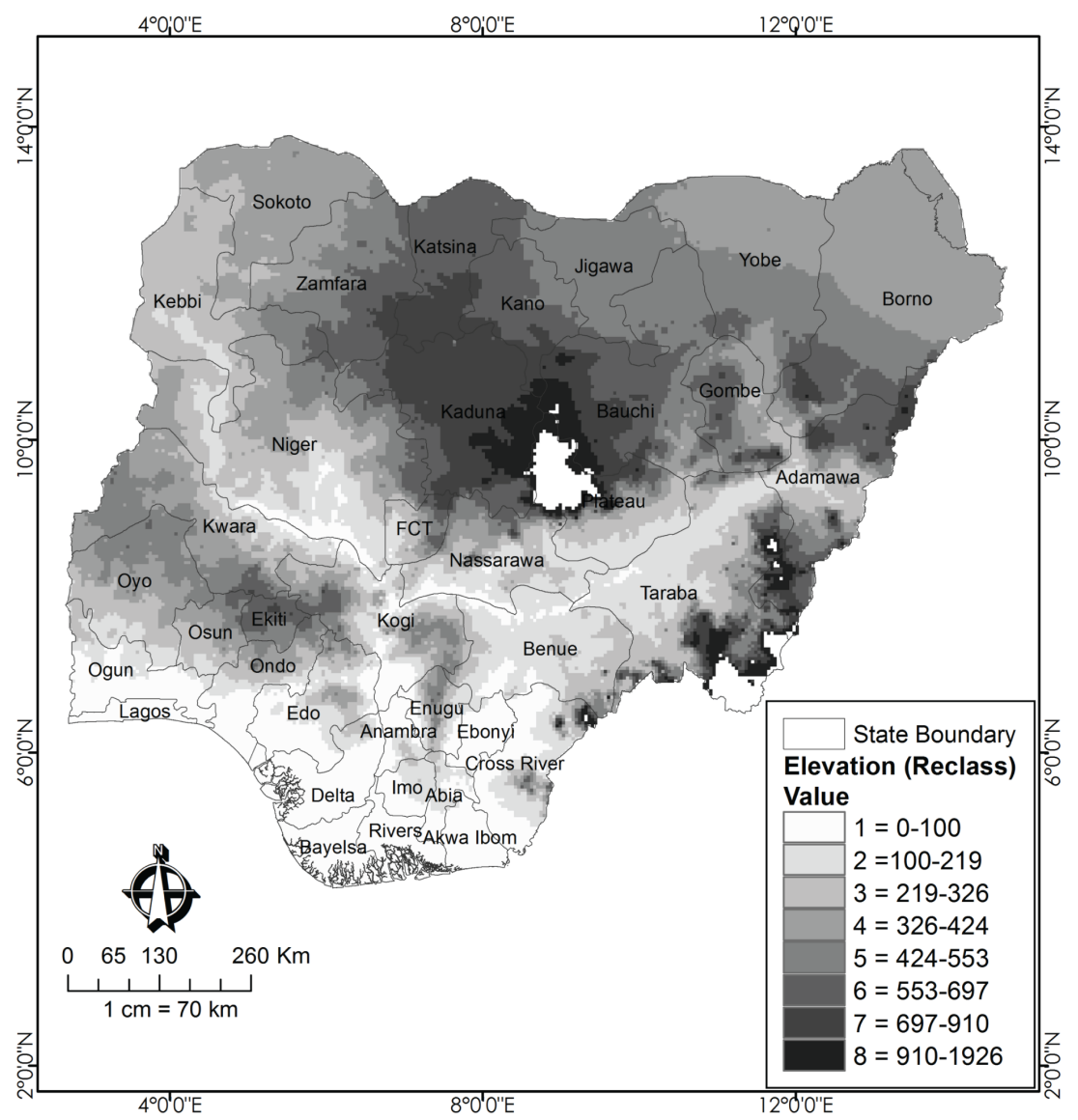

and the Cross River. The Northern part of Nigeria thus has fewer LGAs faced with high flood-risk when compared to the South. This is so because, although there is a fair share of rivers in the North of Nigeria, the elevation is higher (Figure 3) and rainfall is lesser (Figure 5).

There are more LGAs within medium flood-risk zones in the North (120 LGAs in 15 States) with only 5 LGAs within 3 States in the South. This implies that a total of 125 LGAs (16\% of all the LGAs in Nigeria) are in medium flood-risk zones (Figure 12). Further, measurements from the flood-risk map revealed that out of a total coverage area of $924,000 \mathrm{~km}^{2}$, an area of $22,654 \mathrm{~km}^{2}$ is exposed to high risk of flood, $44,923 \mathrm{~km}^{2}$ to medium risk and $5198 \mathrm{~km}^{2}$ to low flood-risk.

The flood-risk vulnerability map in Figure 13 is an overlay of the polygonized flood-risk zones on the population density map of Nigeria. The output reveals the LGAs at different levels of flood vulnerability in Nigeria (Table 4). Lagos State is most vulnerable to flooding, being the only State with LGAs of high population densities within high flood-risk zones. There are 4 LGAs (AjeromiIfelodun, Lagos Island, Shomolu and Mushin) with high population densities that are within high flood-risk zones. Other LGAs, such as Ikorodu, Lagos Mainland, Apapa, Surulere, Eti-Osa and Amuwon-Odofin in Lagos have medium population densities and are as well within high flood-risk zones. Seemingly, more than any other State, residents of Lagos have bemoaned from the feedback of flooding on their livelihoods and in recent times it has become a yearly ritual, especially during the rainy season. 


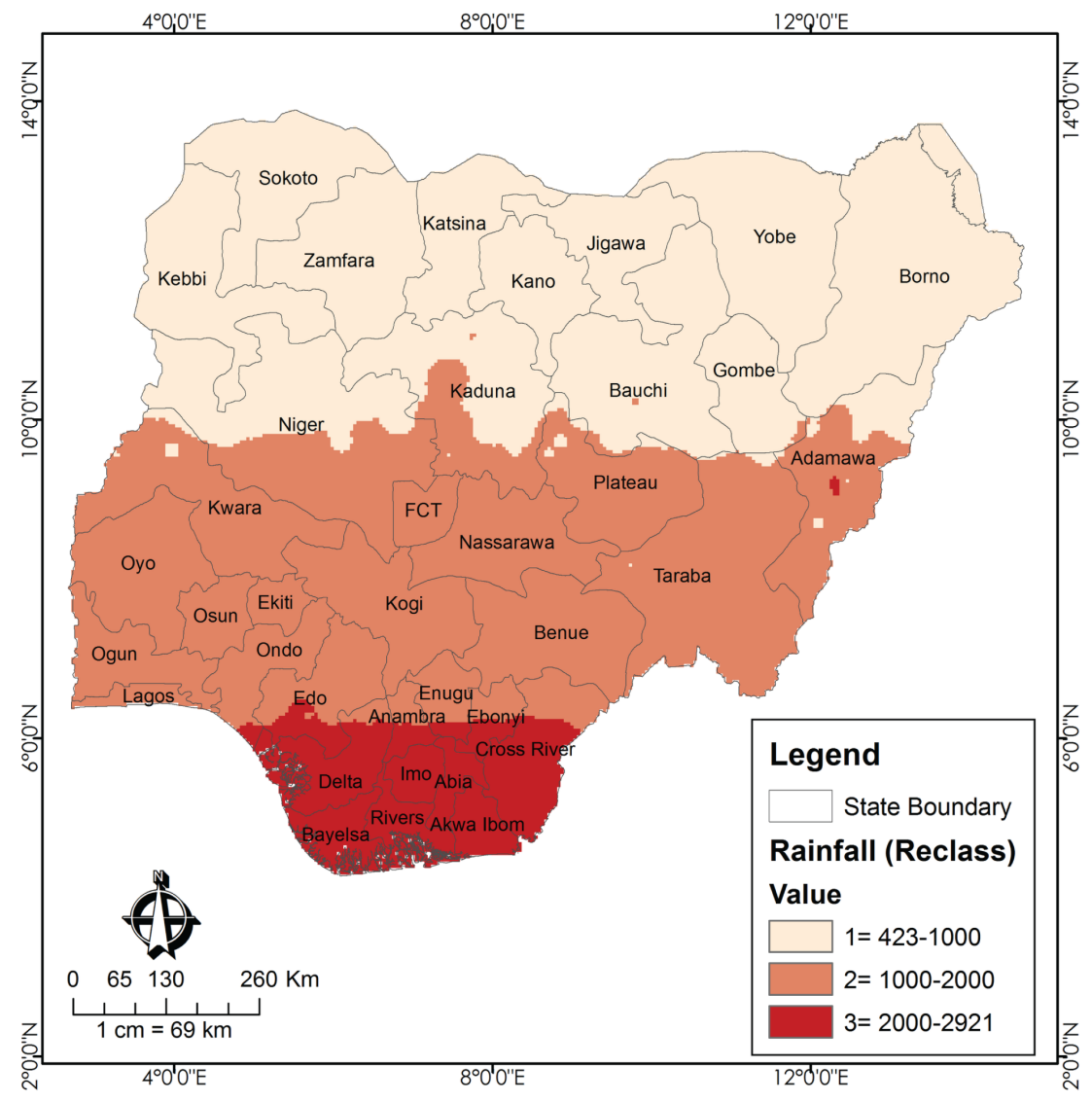

In line with this, The Cable (2019) reported that, "Lagos is turning into an aquatic habitat" as "the flood is geographically redesigning Lagos". In the same vein, Atufu \& Holt (2018) revealed that the flooding in Lagos causes loss of lives and property as well as disruption of movement which hinders socio-economic activities. According to Adelekan \& Asiyanbi (2016), a flood event at the Ikorodu area of Lagos in 2010 led to the displacement of 1700 residents. In 2011, floods in Lagos cost the people a loss of more than US\$300 million, evidenced from insurance claims (Ajibade, McBean \& Bezner-Kerr, 2013). During and after the 2012 deluge which devastated most of the country, it was reported that at least 7.7 million people were affected at different proportions in Lagos alone (Atufu \& Holt, 2018). The figures from Lagos are high compared to other states because of the high population density in Lagos LGAs.

Further, as shown in Table 4, a total of six States (Kogi, Cross River, Akwa Ibom, Delta, Anambra and Rivers) have LGAs with medium population densities that fall within high flood-risk zones, thus facing high flood-risk vulnerability. As well, 4 States (Bauchi, Jigawa, Osun and Borno) face medium flood-risk vulnerability with a total of six LGAs having medium population densities within medium flood-risk zones. These findings corroborate with those from other studies and news reports on flooding in Nigeria, some of which expose the flooding challenge, showing its possible reach, impacts and proffering workable solutions in smaller administrative units (Amangabara \& Obenade, 2015; Njoku, Efiong, Uzoezie, Okeniyi \& Alagbe, 2018; Udo \& Eyoh, 2017). 


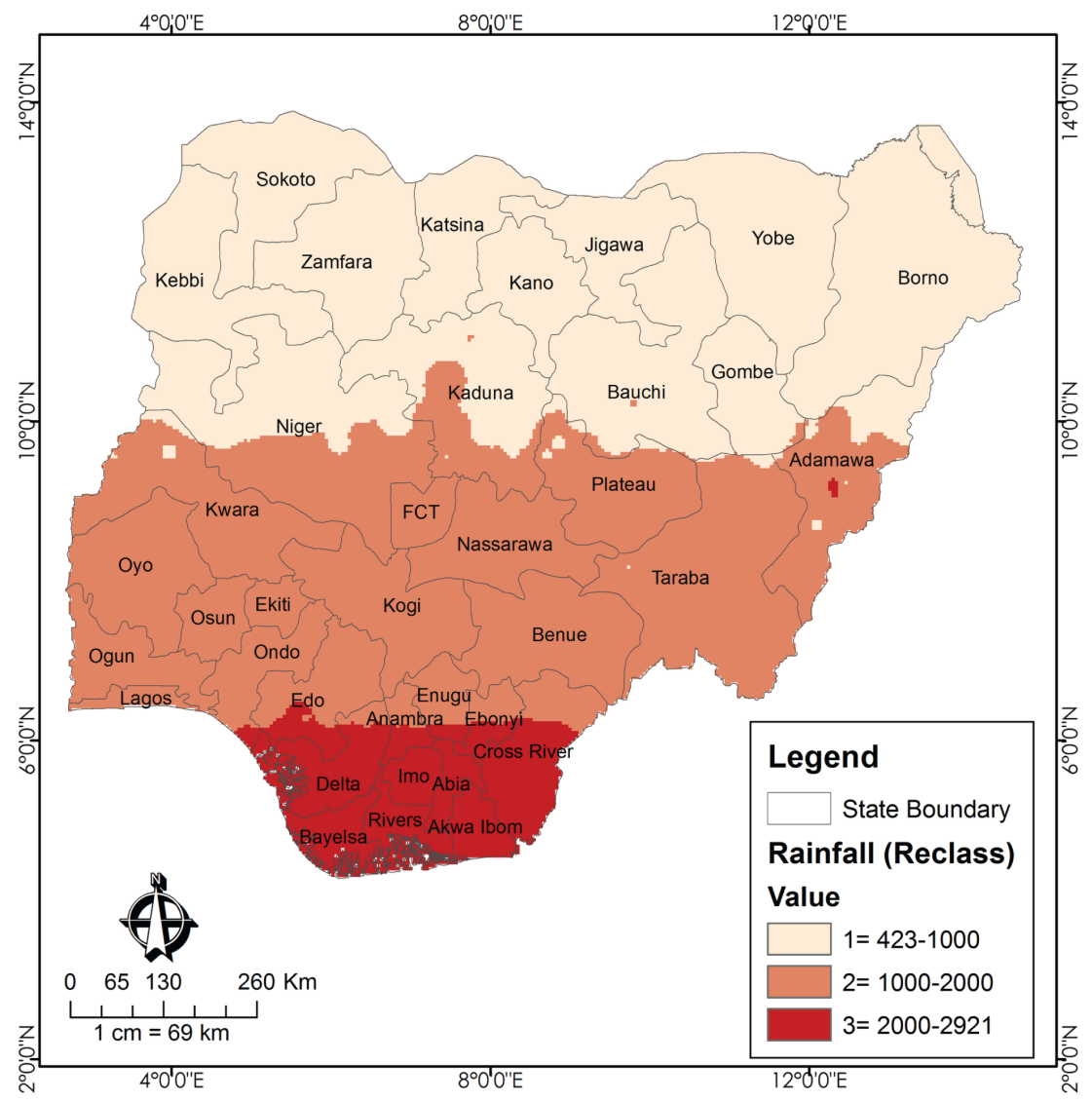

The reports from daily online tabloids go further to support the findings. For instance, Floodlist reported on the $19^{\text {th }}$ of September, 2018 that flooding of rivers prompted a state of emergency in Niger, Kogi, Anambra and Delta States of Nigeria, after the disaster agencies stated that it had killed as many as 100 persons and displaced thousands in communities along the major rivers. Similarly, The Guardian report of $11^{\text {th }}$ May, 2018 quoted the prediction of the Nigeria Hydrological Services Agency (NiHSA) that 35 States in Nigeria would experience flooding in 2018. The floods were predicted to affect 318 LGAs, 78 of which would have high flood-risks. In a related report, as published by The Eagle Online on the $9^{\text {th }}$ of August, 2018, NIMET predicted that cumulative high intensity of rainfall in some parts of the country in June and July of 2018 would trigger floods in which would most likely be intense in Akwa Ibom, Bauchi, Benue, Borno, Lagos, Cross River, Delta, Kaduna, Kwara, Nasarawa, Yobe and Zamfara States.

In October, 2019, the report of the International Federation of Red Cross and Red Crescent Societies (IFRCRCS) affirmed the predictions made in the previous year and substantiated the findings from this study. Following the high-water levels in rivers Niger and Benue, accompanied by heavy rainfall, Cross River, Kogi, Niger and Taraba States experienced flooding in September 2019. A total of 18,640 people (3,104 households) were affected by the floods in 54 communities while some 4,485 people ( 746 households) are were displaced (IFRCRCS, 2019). Further, since June, 2019, IFRCRCS (2019) reported that in Nigeria as a whole, flooding has affected a total of 210,117 people with 171 casualties recorded in hospital and 130,610 people reported to be displaced. The 


\begin{tabular}{|c|c|c|c|c|}
\hline Parameters & Class & $\begin{array}{l}\text { Reclass } \\
\text { (Rates) }\end{array}$ & Rating Index & $\begin{array}{c}\text { Weight } \\
\text { (W) }\end{array}$ \\
\hline \multirow{8}{*}{ Elevation (m) } & $0-100$ & 1 & High risk & \multirow{8}{*}{30} \\
\hline & $100-219$ & 2 & \multirow{7}{*}{ Low risk } & \\
\hline & $219-326$ & 3 & & \\
\hline & $326-424$ & 4 & & \\
\hline & $424-553$ & 5 & & \\
\hline & $553-697$ & 6 & & \\
\hline & $697-910$ & 7 & & \\
\hline & $910-1926$ & 8 & & \\
\hline \multirow{7}{*}{ Slope $(\%)$} & $0-10$ & 1 & High risk & \multirow{7}{*}{20} \\
\hline & $10--15$ & 2 & \multirow{6}{*}{ Low risk } & \\
\hline & $15-20$ & 3 & & \\
\hline & $20-30$ & 4 & & \\
\hline & $30-50$ & 5 & & \\
\hline & $50-80$ & 6 & & \\
\hline & $80-113$ & 7 & & \\
\hline \multirow{3}{*}{ Rainfall intensity (mm) } & $0-1000$ & 1 & Low risk & \multirow{3}{*}{20} \\
\hline & $1000-2000$ & 2 & \multirow{2}{*}{ High risk } & \\
\hline & $2000-2921$ & 3 & & \\
\hline Distance from rivers $(\mathrm{m})$ & $>500$ & 1 & High risk & 10 \\
\hline Distance from big water bodies (m) & $>2000$ & 1 & High risk & 20 \\
\hline
\end{tabular}

floods are experienced in LGAs that are flood prone as this study has shown. In all, the occurrence of flooding in Nigeria is impending and its multi-dimensional impacts on livelihoods may continue if proper measures are not put in place to tackle the menace (Table 5).

\section{CONCLUSION AND RECOMMENDATIONS}

The vulnerability of Nigerians to flood-risk varies across space. The combination of factors such as elevation, slope, rainfall intensity and distance to water bodies resulted to flood-risk and vulnerability maps, revealing LGAs that are in high, medium and low risk zones. Nigeria has 774 LGAs, 30 percent of which are vulnerable to flood-risk at medium and high levels.

This calls for concern and more commitment to flood-risk management, especially in the Southern part of the country where more LGAs are prone to high flood-risks. Lagos showed to be more vulnerable to flooding due to its densely populated LGAs residing within high flood-risk zones. While Lagos stands out, other LGAs like Calabar South in Cross River State, Onitsha North and South in Anambra, and so on are vulnerable too since they have medium population densities and are situated in high flood-risk zones. The prediction of flood-risk zones and vulnerable LGAs in Nigeria as executed in this study is validated by past occurrence of flooding in some of the identified communities from literature and news reports. 


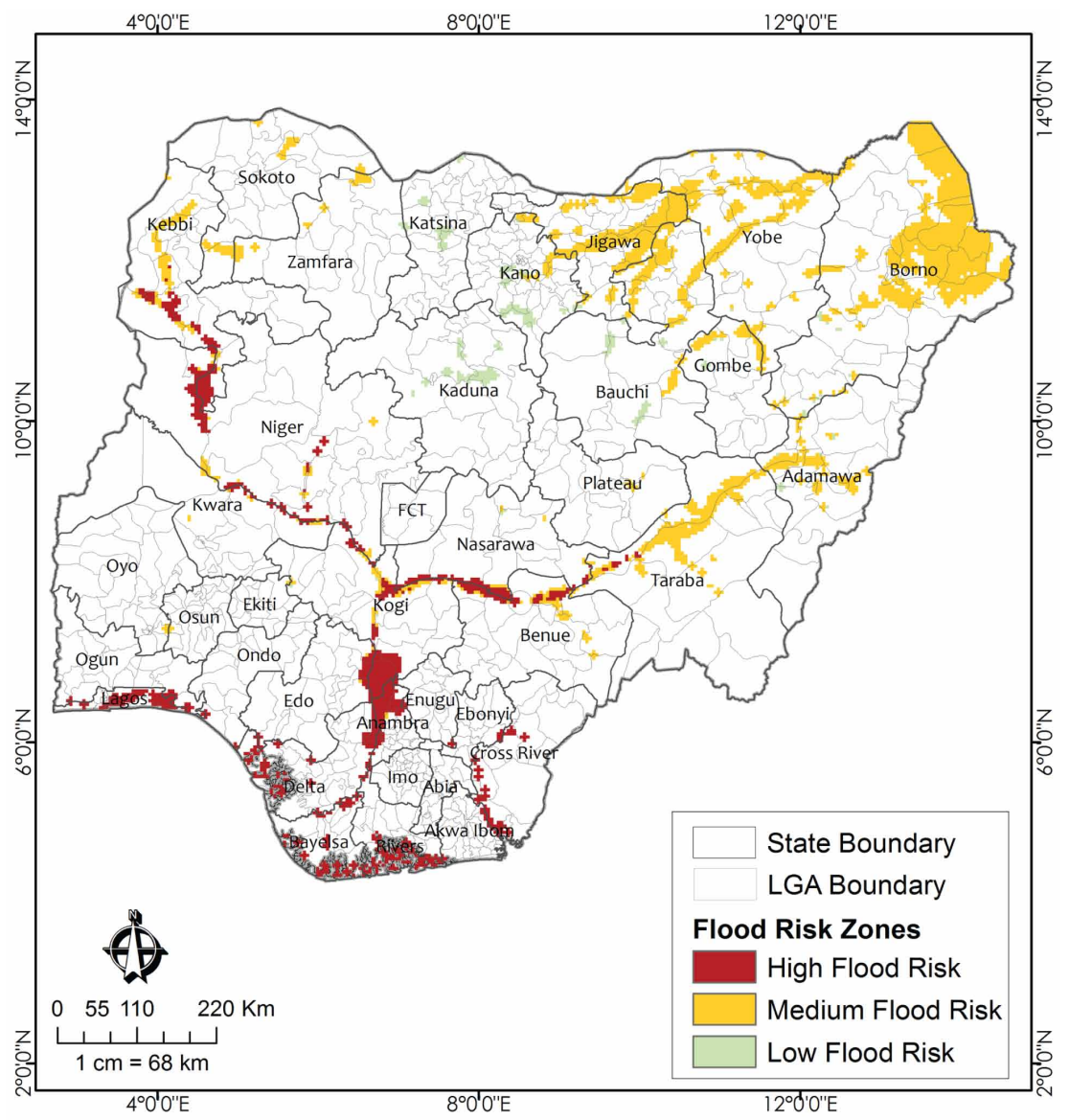

This study presents an inventory of LGAs that are vulnerable to different levels of flood risk in Nigeria. At the national scale, this information is novel, thus its relevance for decision making cannot be overemphasized. The information is relevant at all aspects of flood-risk management as it serves as the bases for evaluating the susceptibilities of physical and social systems to the hazard at the LGAs at risk. It would also go a long way to fill the void in the dearth of flood-risk vulnerability studies and models necessary for evidence-based decision making to mitigate the menace and impacts of flooding on the Nigerian populace.

Based on the findings, the following recommendations are suggested:

1. The flood-risk and vulnerability maps derived from this study should be adopted as working documents to support policy formulation and decision making for specific relevant agencies such as the NIMET, NEMA, NiHSA, IFRCRCS, the Federal and State fire departments, city administrators and planners, and so on;

2. The maps and lists of LGAs at different flood-risk zones are useful in all steps of disaster management (prevention, mitigation, preparedness, operations, relief and recovery). Particularly, this information should be used for early warning and evacuation of settlers to higher grounds in a case of an extreme anthropogenic or climatic event such as the recurrent release of excess water from dams or extreme rainfall occurrence; 


\section{Figure 13. Flood-risk vulnerability in Nigeria}

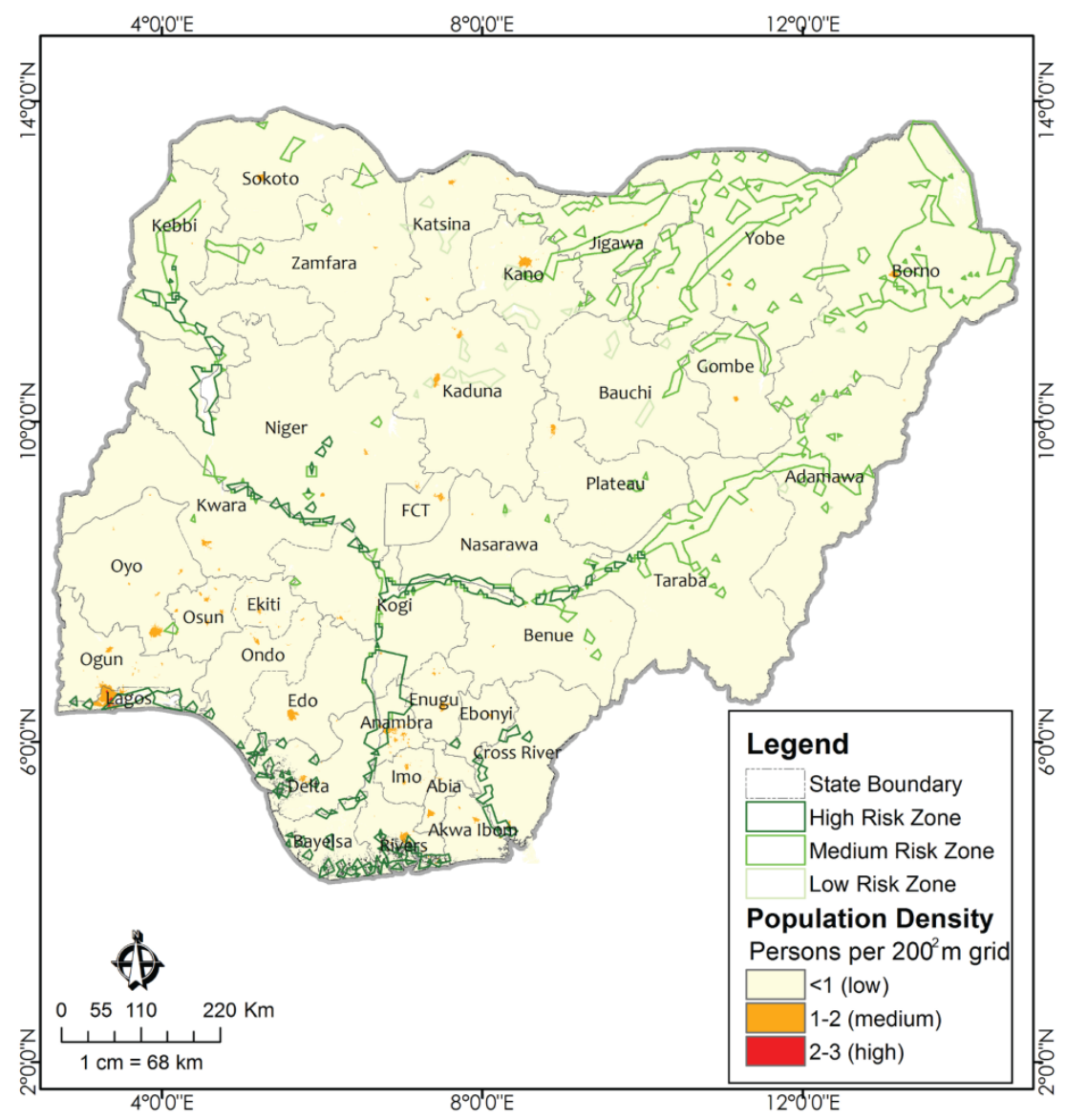

Table 3. LGAs vulnerable to flooding in high flood-risk zones

\begin{tabular}{|l|l|l|l|}
\hline \multicolumn{1}{|c|}{ S/n } & \multicolumn{1}{|c|}{ Ltate } & \multicolumn{1}{c|}{ Total } \\
\hline 1 & Kebbi & Suru, Dandi, Bagudo, Koko/Besse, Shanga & 5 \\
\hline 2 & Niger & Yauri, Agwara, Borgu, Magama, Mokwa, Wushishi, Lavun, Edati, Agaie, Lapai & 10 \\
\hline 3 & Kwara & Pategi, Edu & 2 \\
\hline 4 & Kogi & Lokoja, Ajaokuta, Ofu, Omala, Bassa, Kogi, Idah, Ibaji, Igalamela-Odolu & 9 \\
\hline 5 & Nasarawa & Toto, Nasarawa, Doma, Awe & 4 \\
\hline 6 & Taraba & Wukari, Ibi, Gassol & 3 \\
\hline 7 & Benue & Guma, Makurdi, Guer West, Logo, Agatu & 5 \\
\hline 8 & Ogun & Ipokia, Ado-Odo/ Ota, Ogun Waterside, Ijebu East & 4 \\
\hline 9 & Lagos & $\begin{array}{l}\text { Badagry, Amuwo Odofin, Ajeromi-Ifelodun, Apapa, Lagos Mainland, Lagos } \\
\text { Island, Eti Osa, Kosofe, Surulere, Shomolu, Ikorodu, Ekpe, Ibeju Leki }\end{array}$ & 10 \\
\hline 10 & Ilaje, Ese-Odo & 2 \\
\hline 11 & Ondo & Ekeremor, Southern Ijaw, Sagbama, Nembe, Brass & 5 \\
\hline 12 & Bayelsa & Oguta & 1 \\
\hline
\end{tabular}


Table 3. Continued

\begin{tabular}{|l|l|l|l|}
\hline \multicolumn{1}{|c|}{ S/n } & \multicolumn{1}{|c|}{ State } & \multicolumn{1}{c|}{ LGA } \\
\hline 13 & Delta & $\begin{array}{l}\text { Warri North, Warri South West, Burutu, Warri South, Ethiope West, Ethiope East, } \\
\text { Udu, Ughelli North, Patami, Oshimili North, Oshimili South, Ndokwa East, Isoko } \\
\text { South }\end{array}$ & $\begin{array}{l}\text { 14 } \\
\text { Ogba/Egbema/Ndoni, Akuku Toru, Degbema, Bonny, Okrika, Port-Harcourt, Ogu/ } \\
\text { Bolo, Andoni, Emohua, Opobo/ Nkoro, Khana. }\end{array}$ \\
\hline 14 & Rivers & $\begin{array}{l}\text { Ogbaru, Ekwusigo, Onitsha South, Onitsha North, Idemili North, Idemili South, } \\
\text { Anambra West, Anambra East, Ayamelum, Akwa North }\end{array}$ & 10 \\
\hline 15 & Anambra & Uzo-Uwani, Ezeagu, Aninri \\
\hline 17 & Enugu & Ohaozara, Ivo, Ikwo, Afikpo North \\
\hline 18 & Ebonyi & Ikot Abasi, Uruan, Okobo, Oron, Itu \\
\hline 19 & Akwa Ibom & Calabar South, Calabar Municipality, Odukpani, Biase, Abi, Obubra, Ikom \\
\hline 20 & Cross River & 4 & 4 \\
\hline
\end{tabular}

Table 4. LGAs vulnerable to flooding in medium flood-risk zones

\begin{tabular}{|c|c|c|c|}
\hline $\mathbf{S} / \mathbf{n}$ & State & LGA & Total \\
\hline 1 & Oyo & Egbeda, Lagelu & 2 \\
\hline 2 & Osun & Irewole, Isokan & 2 \\
\hline 3 & Kwara & Moro & 1 \\
\hline 4 & Kogi & Yagba East & 1 \\
\hline 5 & Ekiti & Ikole & 1 \\
\hline 6 & Benue & Tarka, Buruku, Katsina-Ala, Kwande & 4 \\
\hline 7 & Taraba & Wukari, Gassol, Bali, Karim-Lamido, Jalingo, Ardo-Kola & 6 \\
\hline 8 & Plateau & Wase, Kannam, Langtang & 3 \\
\hline 9 & Nasarawa & Akwanga, Lafia & 2 \\
\hline 10 & Adamawa & $\begin{array}{l}\text { Lamurde, Numan, Guyuk, Shelleng, Demsa, Mayo-Belwa, Yola South, Yola } \\
\text { North, Fufore, Girei, Song, Mayo-Belwa }\end{array}$ & 12 \\
\hline 11 & Gombe & Dukku, Nafada, Funakaye & 3 \\
\hline 12 & Kebbi & Bunza, kalgo, Birnin-Kebbi, Argungu & 4 \\
\hline 13 & Sokoto & Tambuwal, Kebbe, Wurno, Illela, Guronyo, Gada & 6 \\
\hline 14 & Zamfara & Gummi, Bakura, Shinkafi, Talata-Mafara, Maradun & 5 \\
\hline 15 & Kano & Dambatta, Dawakin Kudu, Warawa, Gabasawa, Wudil, Ajingi, Takai & 7 \\
\hline 16 & Jigawa & $\begin{array}{l}\text { Garki, Ringim, Taura, Sule-Tankarkar, Babura, Birni-Kudu, Buji, Gwaram, } \\
\text { Kiyawa, Miga, Jahum, Kafin Hausa, Auyo, Kaugama, Hadejia, Kiri Kasamma, } \\
\text { Guri, Biriniwa, Maigatari, Gumel }\end{array}$ & 20 \\
\hline 17 & Bauchi & $\begin{array}{l}\text { Kirfi, Ganjuwa, Shira, Jama'are, Itas/Gadua, Zaki, Gamawa, Damban, Misau, } \\
\text { Darazo }\end{array}$ & 10 \\
\hline 18 & Yobe & $\begin{array}{l}\text { Bade, Karasuwa, Yusufari, Jakusko. Bursari, Yunusari, Geidam, Tarmua, } \\
\text { Damaturu, Nangere, Fune, Gujba, Galani, Fika }\end{array}$ & 14 \\
\hline 19 & Borno & $\begin{array}{l}\text { Shani, Bayo, Itawul, Askira/Uba, Bamboa, Kaga, Konduga, Maiduguri, Jere, } \\
\text { Magumeri, Gwoza, Mafa, Bama, Dikwa, Nganzai, Mobbar, Abadam, Kukawa, } \\
\text { Mongumo, Marte, Ngala, Kala/Balge }\end{array}$ & 22 \\
\hline 20 & Total & & 103 \\
\hline
\end{tabular}


Table 5. LGAs within high and medium flood vulnerability levels

\begin{tabular}{|l|l|l|}
\hline \multicolumn{1}{|c|}{ Vulnerability Level } & \multicolumn{1}{|c|}{ State } & \multicolumn{1}{c|}{ LGA } \\
\hline \multirow{5}{*}{ High vulnerability } & Lagos & Ajeromi-Ifelodun, Lagos Island, Shomolu and Mushin \\
\cline { 2 - 3 } & Kogi & Idah \\
\cline { 2 - 3 } & Cross River & Calabar South \\
\cline { 2 - 3 } & Akwa Ibom & Oron \\
\cline { 2 - 3 } & Delta & Oshimili South \\
\cline { 2 - 3 } & Anambra & Onitsha South, Onitsha North, Idemili South \\
\cline { 2 - 3 } & Rivers & Port-Harcourt, Eleme, Okrika, Ogu/Bolo, Opobo/Nkoro \\
\hline \multirow{5}{*}{ Medium vulnerability } & Lagos & Ikorodu, Lagos Mainland, Apapa, Surulere, Eti-Osa Amuwon-Odofin \\
\cline { 2 - 4 } & Bauchi & Jama'are \\
\cline { 2 - 3 } & Jigawa & Hadeja \\
\cline { 2 - 3 } & Osun & Irewole, Isokan \\
\cline { 2 - 3 } & Borno & Maiduguri, Jere \\
\hline
\end{tabular}

3. To build sustainable rural and urban communities, the findings here should support monitoring or restriction of anthropogenic activities around flood-risk zones. Areas with existing human activities, especially landuses within flood-risk zones should be re-modeled and re-engineered to cater for flood events. Alternatively, residents should be evicted, resettled or advised to relocate, as the case may be. Only these proactive measures would reduce the socio-economic impacts of flooding on livelihoods of residents in Nigeria;

4. Proactive and workable mitigation and adaptation policies must be implemented by the Nigerian government and other stakeholders at local, state or national levels. This would help the LGAs and other players adjust their systems in response to expected effects, thereby moderating possible risks. 


\section{REFERENCES}

Adelekan, I. O., \& Asiyanbi, A. P. (2016). Flood risk perception in flood-affected communities in Lagos, Nigeria. Natural Hazards, 80(1), 445-469. doi:10.1007/s11069-015-1977-2

Ademiluyi, I. A., Okude, A. S., \& Akanni, C. O. (2008). An appraisal of landuse and landcover mapping in Nigeria. African Journal of Agricultural Research, 3(9), 581-586.

Aderogba, K. A. (2012). Qualitative studies of recent floods and sustainable growth and development of cities and towns in Nigeria. International Journal of Academic Research in Economics and Management Sciences, $1(3), 1-25$.

Ajibade, I., McBean, G., \& Bezner-Kerr, R. (2013). Urban flooding in Lagos, Nigeria: Pattern of vulnerability and resilience among women. Global Environmental Change, 23(6), 1714-1725. doi:10.1016/j.gloenvcha.2013.08.009

Ajjur, S. B., \& Mogheir, Y. K. (2020). Flood hazard mapping using a multi-criteria decision analysis and GIS (case study Gaza Governorate, Palestine). Arabian Journal of Geosciences, 13(44), 1-11. doi:10.1007/s12517019-5024-6

Amangabara, G. T., \& Obenade, M. (2015). Flood vulnerability assessment of Niger Delta States relative to 2012 flood disaster in Nigeria. American Journal of Environmental Protection, 3(3), 76-83.

Atufu, C. E., \& Holt, C. P. (2018). Evaluating the impacts of flooding on the residents of Lagos, Nigeria. Urban Water Systems \& Floods II, 184, 81-90. doi:10.2495/FRIAR180081

Billi, P., Alemu, Y. T., \& Ciampalini, R. (2015). Increased frequency of flash floods in Dire Dawa, Ethiopia: Change in rainfall intensity or human impact? Natural Hazards, 76(2), 1373-1394. doi:10.1007/s11069-0141554-0

Blistanova, M., Zelenakova, M., Blistan, P., \& Ferencz, V. (2016). Assessment of flood vulnerability in Bodva River Basin, Slovakia. Acta Montanistica Slovaca, 21(1), 19-28.

Brierley, G., Fryirs, K., Cullum, C., Tadaki, M., Huang, H. Q., \& Blue, B. (2013). Reading the landscape: Integrating the theory and practice of geomorphology to develop place-based understandings of river systems. Progress in Physical Geography, 37(5), 1-21. doi:10.1177/0309133313490007

Brooks, N. (2003). Vulnerability, risk and adaptation: A conceptual framework. Tyndall Centre for Climate Change Research, Working Paper 38. Retrieved January, 2020 from https://gsdrc.org/document-library/vulnerabilityrisk-and-adaptation-a-conceptual-framework/

Cardona, O. D. (2004). The need for rethinking the concepts of vulnerability and risk from a holistic perspective: A necessary review and criticism for effective risk management. In G. Bankoff, G. Frerks, \& D. Hilhorst (Eds.), Mapping vulnerability: Disasters, Development and People. London: Earthscan.

Coninx, I., \& Bachus, K. (2007). Integrating social vulnerability to floods in a climate change context. Higher Institute for Labour Studies, Catholic University of Leuven. Retrieved March, 2020 from https://www.newater. uni-osnabrueck.de/caiwa/data/papers\%20session/D3/Coninx\%20and\%20Bachus.pdf

Crichton, D. (1999). The risk triangle. In J. Ingleton (Ed.), Natural Disaster Management (pp. 102-103). London: Tudor Rose.

Daneshbod, Y. (2014). Flood zone investigation by using satellite and aerial imagery. European Space Agency, Second Space for Hydrology Workshop. Retrieved February, 2020 from http://earth.esa.int/hydrospace07/ abstracts/84220.html

Danumah, J. H., Odai, S. O., Saley, B. M., Szarzynski, J., Thiel, M., Kwaku, A., \& Akpa, L. Y. et al. (2016). Floodrisk assessment and mapping in Abidjan district using multi-criteria analysis (AHP) model and geoinformation techniques, (Cote d'Ivoire). Geoenvironmental Disasters, 3(10), 1-13. doi:10.1186/s40677-016-0044-y

Das, M., Chattopadhya, A., \& Basu, R. (2017). Spatial Flood Potential Mapping (SFPM) with flood probability and exposure indicators of flood vulnerability: Case study former Jalpaiguri District, West Bengal, India. Journal of Geography \& Natural Disasters, 7(3), 1-8. doi:10.4172/2167-0587.1000210 
Efiong, J., \& Hogan, I. S. (2017). Mapping flood risk zones in the Cross-River basin using remote sensing and geographical information systems. Proceedings of the 8th International Conference of Nigeria Association of Hydrological Sciences (NAHS), $161-166$.

Efiong, J., \& Ushie, J. O. (2019). Projected impact of sea level rise on Nigeria's coastal city of Calabar in Cross River State. International Journal of Environment and Climate Change, 9(10), 535-548. doi:10.9734/ ijecc/2019/v9i1030138

Elsheikh, R. F. A., Querghi, S., \& Elhag, A. R. (2015). Flood risk map based on GIS, and multicriteria techniques (case study Terengganu Malaysia). Journal of Geographic Information System, 7(04), 348-357. doi:10.4236/ jgis.2015.74027

Environmental Systems Research Institute. (2014). Understanding Weighted Overlay. Retrieved March, 2020 from https://www.esri.com/about/newsroom/wp-content/uploads/2019/05/understanding-weighted-overlay.pdf

Fadhil, M., Ristya, Y., Oktaviani, N., \& Kusratmoko, E. (2019). Flood vulnerability mapping using the spatial multi-criteria evaluation (SMCE) method in the Minraleng Watershed, Maros Regency, South Sulawesi. Web of Conferences, 153, 2-7.

Fashae, O., Olushola, A., \& Adedeji, O. (2017). Geospatial Analysis of Changes in Vegetation Cover over Nigeria. Bulletin of Geography. Physical Geography Series, 13(1), 17-28. doi:10.1515/bgeo-2017-0010

Fernandez, D. S., \& Lutz, M. A. (2010). Urban flood hazard zoning in Tucumán Province, Argentina, using GIS and multicriteria decision analysis. Engineering Geology, 111(1-4), 90-98. doi:10.1016/j.enggeo.2009.12.006

Forkuo, E. K. (2013). The use of digital elevation models for watershed and flood hazard mapping. International Journal of Remote Sensing and Geoscience, 2(2), 10.

Gandini, A., Prieto, I., Garmendia, L., San-Jose, J-T. \& Egusquiza, A. (2018). Adaptation to flooding events through vulnerability mapping in historic urban areas. The International Archives of the Photogrammetry, Remote Sensing and Spatial Information Sciences, 42(3/W4), 221-226.

Gigović, L., Pamučar, D., Bajić, Z., \& Drobnjak, S. (2017). Application of GIS interval rough AHP methodology for flood hazard mapping in urban areas. Water (Basel), 9(6), 1-26. doi:10.3390/w9060360

Hawker, L., Bates, P., Neal, J., \& Rougier, J. (2018). Perspectives on Digital Elevation Model (DEM) simulation for flood modeling in the absence of a high-accuracy open access global DEM. Frontiers of Earth Science, 6(233), 1-9.

Hoque, M. A., Pradhan, B., \& Ahmed, M. (2019). Assessing drought vulnerability using geospatial techniques in northwestern part of Bangladesh. The Science of the Total Environment, 1-35. doi:10.1016/j. scitotenv.2019.135957 PMID:31841918

Horritt, M., \& Bates, P. (2002). Evaluation of 1D and 2D numerical models for predicting river flood inundation. Journal of Hydrology (Amsterdam), 268(1-4), 87-99. doi:10.1016/S0022-1694(02)00121-X

Humanitarian Data Exchange. (2018). Nigeria-Water Courses (Rivers). Retrieved June 2018 from https://data. humdata.org/dataset/nigeria-water-courses

IFRCRCS. (2019). Emergency Plan of Action (EPoA). Nigeria: Floods. Retrieved October, 2019 from https:// reliefweb.int/sites/reliefweb.int/files/resources/MDRNG028do.pdf

Karmakar, S., Simonovic, S. P., Peck, A., \& Black, J. (2010). An information system for risk-vulnerability assessment to flood. Journal of Geographic Information System, 2(03), 129-146. doi:10.4236/jgis.2010.23020

Kazakis, N., Kougias, I., \& Patsialis, T. (2015). Assessment of flood hazard areas at a regional scale using an index-based approach and Analytical Hierarchy Process: Application in Rhodope-Evros region, Greece. The Science of the Total Environment, 538, 555-563. doi:10.1016/j.scitotenv.2015.08.055 PMID:26318691

Kim, B. S., \& Kim, H. S. (2014). Evaluation of flash flood severity in Korea using the modified flash flood index (MFFI). Journal of Flood Risk Management, 7(4), 344-356. doi:10.1111/jfr3.12057

Komolafe, A. A., Adegboyega, S. A.-A., \& Akinluyi, F. O. (2015). A review of flood-risk analysis in Nigeria. American Journal of Environmental Sciences, 11(3), 157-166. doi:10.3844/ajessp.2015.157.166 
Liu, W., Dugar, S., McCallum, I., Thapa, G., See, L., Khadka, P., \& Shakya, P. et al. (2018). Integrated participatory and collaborative risk mapping for enhancing disaster resilience. ISPRS International Journal of Geo-Information, 68(2), 1-23. doi:10.3390/ijgi7020068

Liu, X. (2013). GIS-Based Local Ordered Weighted Averaging: A Case Study in London, Ontario. Electronic Thesis and Dissertation Repository. 1227. Retrieved March, 2020 from https://ir.lib.uwo.ca/etd/1227

Malczewski, J., \& Rinner, C. (2015). Multicriteria decision analysis in geographic information science. Advances in Geographic Information Science. Retrieved February, 2020 from https://www.springer.com/gp/ book/9783540747567\#aboutBook

McCarthy, J. J., Canziani, A. F., Leary, N. A., Dokken, D. J., \& White, K. S. (Eds.). (2001). Climate change 2001: impacts, adaptation, and vulnerability (p. 1032). Cambridge: Cambridge University Press.

Meena, Y. R., \& Gupta, A. K. (2017). A study on urban flood vulnerability in Vrishabhavathi Valley Watershed, Bengaluru, Karnataka using AHP, GIS and RS techniques. International Journal of Advanced Remote Sensing and GIS, 6(1), 2325-2342. doi:10.23953/cloud.ijarsg.298

Mokarram, M., \& Hojati, M. (2017). Using Ordered Weight Averaging (OWA) for multi-criteria soil fertility evaluation by GIS (case study: Southeast Iran). Computers and Electronics in Agriculture, 132, 1-13. doi:10.1016/j.compag.2016.11.005

Musungu, K., Motala, S., \& Smit, J. (2012). Using multi-criteria evaluation and GIS for flood risk analysis in informal settlements of Cape Town: The case of Graveyard Pond. South African Journal of Geomatics, 1(1), 77-91.

Najibi, N., \& Devineni, N. (2017). Recent trends in the frequency and duration of global floods. Earth Systems Dynamics, 9(2), 757-783. doi:10.5194/esd-9-757-2018

National Geographic. (2018). Floods. Retrieved February 2018 from https://www.nationalgeographic.com/ environment/natural-disasters/floods/

Nigerian Meteorological Agency. (2017). 2017 Seasonal Rainfall Prediction (SRP). Retrieved April, 2018 from http://www.nimet.gov.ng/publication/2017-seasonal-rainfall-prediction-srp

Njoku, C. G., Efiong, J., Uzoezie, A. C., Okeniyi, O. O., \& Alagbe, A. O. (2018). A GIS Multi-Criteria Evaluation for Flood-risk-Vulnerability Mapping of Ikom Local Government Area, Cross River State. Journal of Geography. Environment and Earth Science International, 15(2), 1-17. doi:10.9734/JGEESI/2018/40527

Nkwunonwo, U. C., Malcolm, W., \& Brian, B. (2015). Flooding and risk reduction in Nigeria: Cardinal gaps. Journal of Geography and Natural Disasters, 5(1), 1-12.

Ogato, G. S., Bantider, A., Abebe, K., \& Geneletti, D. (2020). Geographic information system (GIS)-Based multicriteria analysis of flooding hazard and risk in Ambo Town and its watershed, West Shoa Zone, Oromia Regional State, Ethiopia. Journal of Hydrology. Regional Studies, 27, 1-18. doi:10.1016/j.ejrh.2019.100659

Ojiakor, G. U. (2009). Nigerian Water Resources and their Management. Water International, 10(2), 64-72. doi: $10.1080 / 02508068508686310$

Orok, H. I. (2011). A GIS-Based Flood Risk Mapping of Kano City, Nigeria (Master's thesis). University of East Anglia, University Plain.

Ouma, Y. O., \& Tateishi, R. (2014). Urban flood vulnerability and risk mapping using integrated multiparametric AHP and GIS: Methodological overview and case study assessment. Water (Basel), 6(6), 1515-1545. doi:10.3390/w6061515

Peduzzi, P., Dao, H., Herold, C., \& Mouton, F. (2009). Assessing global exposure and vulnerability towards natural hazards: The disaster risk index. Natural Hazards and Earth System Sciences, 9(4), 1149-1159. doi:10.5194/ nhess-9-1149-2009

Rimba, A. B., Setawati, M. D., Samba, A. B., \& Miura, F. (2017). Physical flood vulnerability mapping applying geospatial techniques in Okazaki City, Aichi Prefecture, Japan. Urban Science, 1(70), 1-22. doi:10.3390/ urbansci1010007

Samanta, S., Koloa, C., Pal, D. K., \& Palsamanta, B. (2016). Flood-risk Analysis in Lower Part of Markham River Based on Multi-Criteria Decision Approach (MCDA). Hydrology, 3(29), 1-13. doi:10.3390/hydrology3030029 
Siddayao, G. P., Valdez, S. E., \& Fernandez, P. L. (2014). Analytic Hierarchy Process (AHP) in spatial modeling for floodplain risk assessment. International Journal of Machine Learning and Computing, 4(5), 450-457. doi:10.7763/IJMLC.2014.V4.453

Strahler, A. N. (1957). Quantitative analysis of watershed geomorphology. American Geophysical Union Transactions, 38(6), 912-920. doi:10.1029/TR038i006p00913

Suleiman, Y. M., Matazu, M. B., Davids, A. A., \& Mozie, M. B. (2014). The Application of geospatial techniques in flood risk and vulnerability mapping for disaster management at Lokoja, Kogi State, Nigeria. Journal of Environment and Earth Science, 4(5), 54-61.

The Cable. (2019). 'It is turning into an aquatic habitat'- reactions trail flooding in Lagos. Retrieved October, 2019 from https://www.thecable.ng/turning-aquatic-habitat-reactions-trail-flooding-lagos

Thomalla, F., Downing, T., Spanger-Siegfried, E., Han, G., \& Rockström, J. (2006). Reducing hazard vulnerability: Towards a common approach between disaster risk reduction and climate adaptation. Disasters, 30(1), 39-48. doi:10.1111/j.1467-9523.2006.00305.x PMID:16512860

Udani, P. M., \& Mathur, D. K. (2016). Flood hazard vulnerability mapping using remote sensing \& GIS: A case study along the villages of Anand Taluka. Advances in Applied Science Research, 7(3), 214-221.

Udo, E., \& Eyoh, A. (2017). River inundation and flood hazard zonation in Edo State using geospatial technique. International Journal of Engineering Science, 6(8), 48-59.

Udo, E. A., Ojinnaka, O. C., Baywood, C. N., \& Gift, U. A. (2015). Flood hazard analysis and damage assessment of 2012 flood in Anambra State using GIS and remote sensing approach. American Journal of Geographic Information System, 4(1), 38-51.

Umar, N. K., Abdullahi, H. S., \& Usman, A. K. (2019). A multi-criteria decision support system in the analysis of flood risk and vulnerability mapping in Suleja, Niger state, Nigeria. Proceedings of the International Cartographic Association. 29th International Cartographic Conference (ICC 2019). Retrieved February, 2020 from https:// www.proc-int-cartogr-assoc.net/2/137/2019/

Wicht, M., \& Osinska-Skotak, K. (2016). Identifying urban areas prone to flash floods using GIS - preliminary results. Hydrology and Earth System Sciences, 518, 1-22.

Wilde, G. J. S. (1982). The theory of risk homeostasis: Implications for safety and health. Risk Analysis, 2(4), 209-225. doi:10.1111/j.1539-6924.1982.tb01384.x

World Bank. (2018). Nigeria - Population density (2015). Retrieved July 2019 from Energydata.info at https:// energydata.info/dataset/nigeria-population-density-2015/resource/3b61d4b8-a5a9-4149-8958-a7d41304f9b1

Yahaya, S., Ahmad, N., \& Abdalla, R. F. (2010). Multi-criteria analysis for flood vulnerable areas in HadejiaJama'are River Basin, Nigeria. European Journal of Scientific Research, 42(1), 71-83. 
Chukwudi Gbadebo Njoku is a Geographic Information Systems (GIS) and research Consultant with about 9 years experience working with individuals, government institutions and projects funded by international organizations such as the World Bank, UKAID, etc. He has a Bachelor of Science in Geography and Environmental Management, a Post Graduate Diploma in GIS and an M.Sc. in Geography and Environmental Science (Population and Development Studies) from the University of Calabar, Nigeria. He is currently a PhD Candidate in the same programme and institution as his M.Sc. He has published widely on topics such as population growth, disaster-risk management, urban sustainability (housing, water, etc.), conflict, crime, land use/land cover dynamics, poverty, land suitability and sustainability, etc. Chukwudi combines his research prowess and technical efficiencies to get the best results necessary for evidence-based decision making. As a practicing Geographer, apart from solving spatial problems, Chukwudi loves to travel.

Joel Efiong holds a bachelor of Science degree in Geology from the University of Calabar, Calabar, Nigeria in 1998 and Masters in Environmental Resource Planning and Management from the same University in 2004. He then proceeded and obtained a PhD in Geography and Regional Planning with specialisation in Hydro-geomorphology in 2010. He further holds a masters in Geographical Information Systems from the University of Leicester, England, UK. He has over 10 years of university's experience in Teaching and research. His research interest include geomorphometry, environmental management and spatial analytic with emphasis on multi-criteria approaches to solving environmental problems. He has published widely.

Nse-Abasi Ndiyo Ayara holds a Bachelor and Master's degree in Geography and Environmental Science from the University of Calabar, Nigeria, with a bias in Urban Studies where he applies Geographic Information Systems (GIS) in solving urban challenges such as mobility, flooding, accessibility and crime. He has attended numerous local and international training workshops on GIS/Remote Sensing. In addition, Nse-Abasi is a Certified Nuclear Security Professional (CNSP) and a member of the World Institute for Nuclear Security (WINS) where he is exploring the possible applications of GIS/Remote Sensing in nuclear non-proliferation issues and national security. He likes to explore nature in the outdoors through hiking and traveling. 